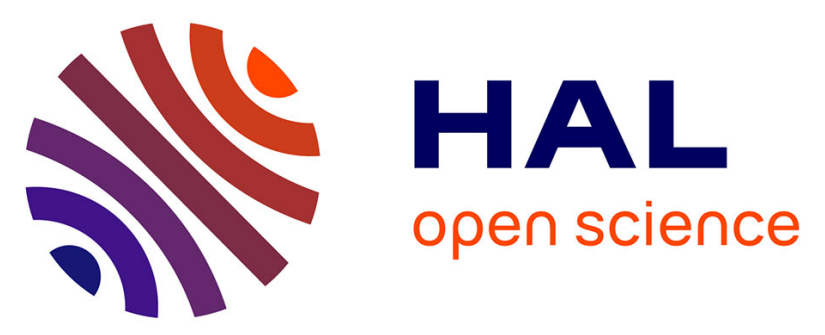

\title{
Early exhumation of high-pressure rocks in extrusion wedges: Cycladic blueschist unit in the eastern Aegean, Greece, and Turkey
}

U. Ring, T. Will, J. Glodny, C. Kumerics, K. Gessner, S. Thomson, T. Gungor, Patrick Monie, M. Okrusch, K. Druppel

\section{To cite this version:}

U. Ring, T. Will, J. Glodny, C. Kumerics, K. Gessner, et al.. Early exhumation of high-pressure rocks in extrusion wedges: Cycladic blueschist unit in the eastern Aegean, Greece, and Turkey. Tectonics, 2007, 26 (2), pp.TC2001. 10.1029/2005TC001872 . hal-00405013

\section{HAL Id: hal-00405013 https://hal.science/hal-00405013}

Submitted on 23 Mar 2021

HAL is a multi-disciplinary open access archive for the deposit and dissemination of scientific research documents, whether they are published or not. The documents may come from teaching and research institutions in France or abroad, or from public or private research centers.
L'archive ouverte pluridisciplinaire HAL, est destinée au dépôt et à la diffusion de documents scientifiques de niveau recherche, publiés ou non, émanant des établissements d'enseignement et de recherche français ou étrangers, des laboratoires publics ou privés. 


\title{
Early exhumation of high-pressure rocks in extrusion wedges: Cycladic blueschist unit in the eastern Aegean, Greece, and Turkey
}

\author{
Uwe Ring, ${ }^{1}$ Thomas Will, ${ }^{2}$ Johannes Glodny, ${ }^{3}$ Christine Kumerics, ${ }^{4}$ Klaus Gessner, ${ }^{5}$ \\ Stuart Thomson, ${ }^{6}$ Talip Güngör, ${ }^{7}$ Patrick Monié, ${ }^{8}$ Martin Okrusch, ${ }^{2}$ and Kirsten Drüppel ${ }^{9}$
}

Received 23 June 2005; revised 8 August 2006; accepted 10 October 2006; published 1 March 2007.

[1] Structural, metamorphic, and geochronologic work shows that the Ampelos/Dilek nappe of the Cycladic blueschist unit in the eastern Aegean constitutes a wedge of high-pressure rocks extruded during early stages of orogeny. The extrusion wedge formed during the incipient collision of the Anatolian microcontinent with Eurasia when subduction and deep underthrusting ceased and the Ampelos/Dilek nappe was thrust southward over the greenschist-facies Menderes nappes along its lower tectonic contact, the Cycladic-Menderes thrust, effectively cutting out a $\sim 30$ - to 40-km-thick section of crust. The upper contact of the Ampelos/Dilek extrusion wedge is the top-to-the-NE Selçuk normal shear zone, along which the Ampelos/Dilek nappe was exhumed by $\sim 30-40 \mathrm{~km}$. Detailed $\mathrm{Rb}-\mathrm{Sr}$ and ${ }^{40} \mathrm{Ar} /{ }^{39} \mathrm{Ar}$ dating of mylonites demonstrates that both shear zones operated between 42 and $32 \mathrm{Ma}$. There is no evidence for episodic motion during the $\sim 10$ Myr life span of the shear zones, suggesting that both shear zones operated in a steady, nonepisodic fashion. Our data provide supporting evidence that simultaneous thrust-type and normal sense shearing can accomplish the early exhumation of deep-seated rocks. Citation: Ring, U., T. Will, J. Glodny, C. Kumerics, K. Gessner, S. Thomson, T. Güngör, P. Monié, M. Okrusch, and K. Drüppel (2007), Early exhumation of high-pressure rocks in extrusion wedges: Cycladic blueschist unit in the eastern Aegean, Greece, and Turkey, Tectonics, 26, TC2001, doi:10.1029/2005TC001872.

\footnotetext{
${ }^{1}$ Department of Geological Sciences, Canterbury University, Christchurch, New Zealand.

${ }^{2}$ Institut für Mineralogie, Universität Würzburg, Würzburg, Germany

${ }^{3}$ GeoForschungsZentrum Potsdam, Potsdam, Germany.

${ }^{4}$ Institut für Geowissenschaften, Johannes Gutenberg-Universität, Mainz, Germany.

${ }^{5}$ School of Earth and Geographical Sciences, University of Western Australia, Crawley Western Australia, Australia.

${ }^{6}$ Department of Geology and Geophyiscs, Yale University, New Haven, Connecticut, USA.

${ }^{7}$ Jeoloji Mühendisligi Bölümü, Dokuz Eylül Üniversitesi, Bornova, Turkey.

${ }^{8}$ UMR 5573, Université Montpellier II, Montpellier, France.

${ }^{9}$ Institut für Mineralogie, Technische Universität, Berlin, Germany.

Copyright 2007 by the American Geophysical Union. 0278-7407/07/2005TC001872
}

\section{Introduction}

[2] The bulk of the exhumation of (ultra)high-pressure rocks usually occurs soon after these rocks were metamorphosed following lithospheric convergence and deep underthrusting during early orogenic stages [Avigad et al., 1997; Reddy et al., 1999; Ring et al., 1999a; Gessner et al., 2001a; de Sigoyer et al., 2001]. A number of studies have demonstrated great exhumation rates during these early exhumation stages [Rubatto and Herrmann, 2001; Baldwin et al., 2005; Glodny et al., 2005a]. It is poorly understood, however, how this early exhumation is being kinematically achieved. One possibility is extrusion wedges, which are characterized by a thrust-type shear zone at their base and a normal-sense shear zone at their top (Figure 1). Because early exhumation often occurs at high rates, the bounding shear zones or faults of extrusion wedges have to slip at even higher rates [Ring and Reischmann, 2002]. It is crucial to define the distribution of internal deformation in an extrusion wedge. If deformation is concentrated along the boundaries, it results in the extrusion of a rigid crustal wedge [Burchfiel and Royden, 1985; Hodges et al., 1992]. Alternatively, the deformation may be distributed throughout the wedge, resulting in ductile extrusion [Grujic et al., 1996].

[3] The classic example of an extrusion wedge is the Greater Himalayan crystalline complex bounded by the Main Central thrust at its base and the south Tibetan detachment at its top [Burchfiel and Royden, 1985], both of which are thought to have slipped contemporaneously in the early Miocene [Hodges et al., 1992]. The debate on whether slip at both shear zones was contemporaneous or not continued for the last two decades. Arguably slip at the Main Central thrust occurred during punctuated events at $\sim 22 \mathrm{Ma}, 15-14 \mathrm{Ma}, 12-10 \mathrm{Ma}$, and 6-3 Ma [Hodges et al., 1996; Coleman, 1998; Harrison et al., 1997; Catlos et al., 2004]. The timing of slip at the south Tibetan detachment remains somewhat more equivocal. Hodges et al. [1998] argued that slip occurred between 22 and $16 \mathrm{Ma}$, whereas Murphy and Harrison [1999] provided evidence that slip at the south Tibetan detachment occurred between 17 and $11 \mathrm{Ma}$ and thus in a period when the Main Central thrust was not active. Catlos et al. [2004] refined the latter date and speculated that normal slip occurred during two distinct short-lived periods at $\sim 17 \mathrm{Ma}$ and $15-14 \mathrm{Ma}$. According to Murphy and Harrison [1999] and Catlos et al. [2004], it appears that deformation in the Greater Himalaya is more consistent with alternating periods of shortening and extension. However, it might be questioned whether ductile shear zones really operate in a strongly 


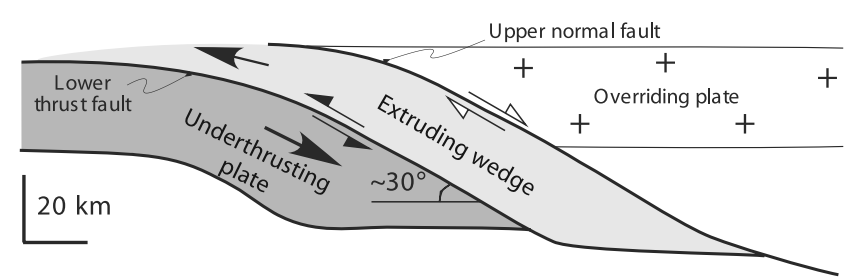

Figure 1. Schematic sketch of extrusion wedge defined by thrust-type shear zone at base and normal-sense shear zone at top. Recent work [Thomson et al., 1998; Ring et al., 2001a; Ring and Reischmann, 2002] suggests that 30-45 dipping extrusion wedges may cause extremely fast (up to $30-35 \mathrm{~km} \mathrm{Myr}{ }^{-1}$ ) exhumation of high- and ultrahighpressure rocks; for such cases, displacement rates at bounding shear zones are up to $40-70 \mathrm{~km} \mathrm{Myr}^{-1}$.

episodic fashion or whether this apparent episodicity is an artifact of dating. Hence others argue that the available data indicate protracted ductile shearing along both the south Tibetan detachment and the Main Central thrust between 22 and $12 \mathrm{Ma}$ (D. Grujic, written communication, 2006). The controversy on the timing of slip in the Greater Himalayas highlights the importance of dating mylonitic deformation of critical tectonic contacts. Further, it is essential to determine pressure-temperature (PT) conditions and deformation/ metamorphism relationships for constraining the amount of excised section and exhumation.

[4] Evidence for a Miocene extrusion wedge accomplishing the early exhumation of high-pressure rocks in the External Hellenides very soon after their metamorphic overprint has been shown for the island of Crete in the southern Aegean [Thomson et al., 1998, 1999], where the fast slipping, large-magnitude Cretan detachment operated coevally with the early Miocene subduction thrust [Ring et al., 2001a; van Hinsbergen et al., 2005]. Critical for the Cretan extrusion wedge is that it was exhumed in the footwall of a former subduction thrust that was reactivated as a weak, low-angle normal detachment when the subduction thrust jumped outboard as a consequence of slab retreat [Ring and Reischmann, 2002].

[5] The exhumation of the Cycladic blueschist unit in the central Aegean has been widely attributed to extensional faulting along a few large-scale detachments faults [Lister et al., 1984]. A number of studies have shown that most of these detachments operated in the Miocene and accomplished only limited exhumation of the Cycladic blueschist unit [Avigad et al., 1997; Keay et al., 2001; Ring et al., 2003a; Kumerics et al., 2005; Brichau et al., 2006]. However, geologic constraints demand $30-40 \mathrm{~km}$ of exhumation of high-pressure rocks soon after their Eocene highpressure metamorphism [Ring et al., 1999b; Gessner et al., 2001a], but it is unknown by which process this early exhumation was accomplished. Ring et al. [2007] argued that the Cycladic blueschist unit on southern Evia Island in the westernmost Aegean Sea was exhumed in an Oligocene extrusion wedge.
[6] Herein we present evidence for wedge extrusion of parts of the eastern Cycladic blueschist unit that achieved $\sim 30-40 \mathrm{~km}$ of exhumation in the late Eocene. We demonstrate that thrust-related mylonitic deformation in the footwall shear zone occurred contemporaneously with ductile normal shearing in the hanging wall shear zone.

\section{Tectonic Setting}

[7] Previous research has outlined several tectonic zones in the Hellenide-Anatolide orogen in the eastern Mediterranean. The tectonic zones are distinguished by rock type, stratigraphy, tectonometamorphic history and preorogenic paleogeography [Dürr et al., 1978; Robertson et al., 1991]. The Hellenides can be subdivided from top (internides) to bottom (externides) into (1) the Internal zones, (2) the Vardar-İzmir-Ankara zone, (3) the Pelagonian zone and the correlative Lycian nappes, (4) the Cycladic blueschist unit, and (5) the External Hellenides. The orogen displays along-strike differences in its architecture [Ring et al., 1999c] where the major dissimilarity between the Hellenides and the Anatolides of western Turkey is that in the latter the Menderes nappes as part of Anatolia, instead of the External Hellenides as part of Apulia, form the lowermost exposed unit. The Anatolian microcontinent collided with Eurasia further east than Apulia (Figure 2).

[8] The internal zones are considered part of Eurasia underneath which oceanic crust of Neotethys was subducted. The related suture is the ophiolitic Vardar-İzmirAnkara zone. The Lycian nappes are a thin-skinned thrust belt, which is assumed to root in the Vardar-İzmir-Ankara zone [Collins and Robertson, 1998]. The Lycian nappes and the structurally equivalent Pelagonian zone are underlain by the Cycladic blueschist unit, the latter of which comprises from top to bottom three composite nappes: (1) an ophiolitic mélange, (2) a Permocarboniferous to latest Cretaceous passive-margin sequence, and (3) a Carboniferous basement, which also occurs as slices in the passive-margin sequence. The Basal unit as part of the External Hellenides occurs below the Cycladic blueschist unit and is exposed in the Olympos window, on the Attica peninsula and on Evia, Tinos, and Samos islands (Figure 2).

[9] The Menderes nappes form the structurally lowest exposed part of the Anatolides in western Turkey. Four main nappes can be distinguished that were juxtaposed in the Eocene by greenschist-facies out-of-sequence thrusting [Ring et al., 1999c, 2001b; Gessner et al., 2001a; Régnier et al., 2003]. From top to bottom these are (1) the Selimiye nappe, (2) the Çine nappe, (3) the Bozdag nappe, and (4) the Bayindir nappe (Figures 3 and 4).

[10] The lowermost tectonic units in the Hellenides and Anatolides show certain geologic/structural dissimilarities, which are caused by tectonic differences of both areas since the late Eocene [Ring et al., 1999c; Gessner et al., 2001a]. In the Anatolides, the collision of the Anatolian microcontinent caused a cessation of deep underthrusting and high-pressure metamorphism, whereas further west the subduction zone retreated southward and caused a Miocene high-pressure belt in the External Hellenides (Figure 2). 


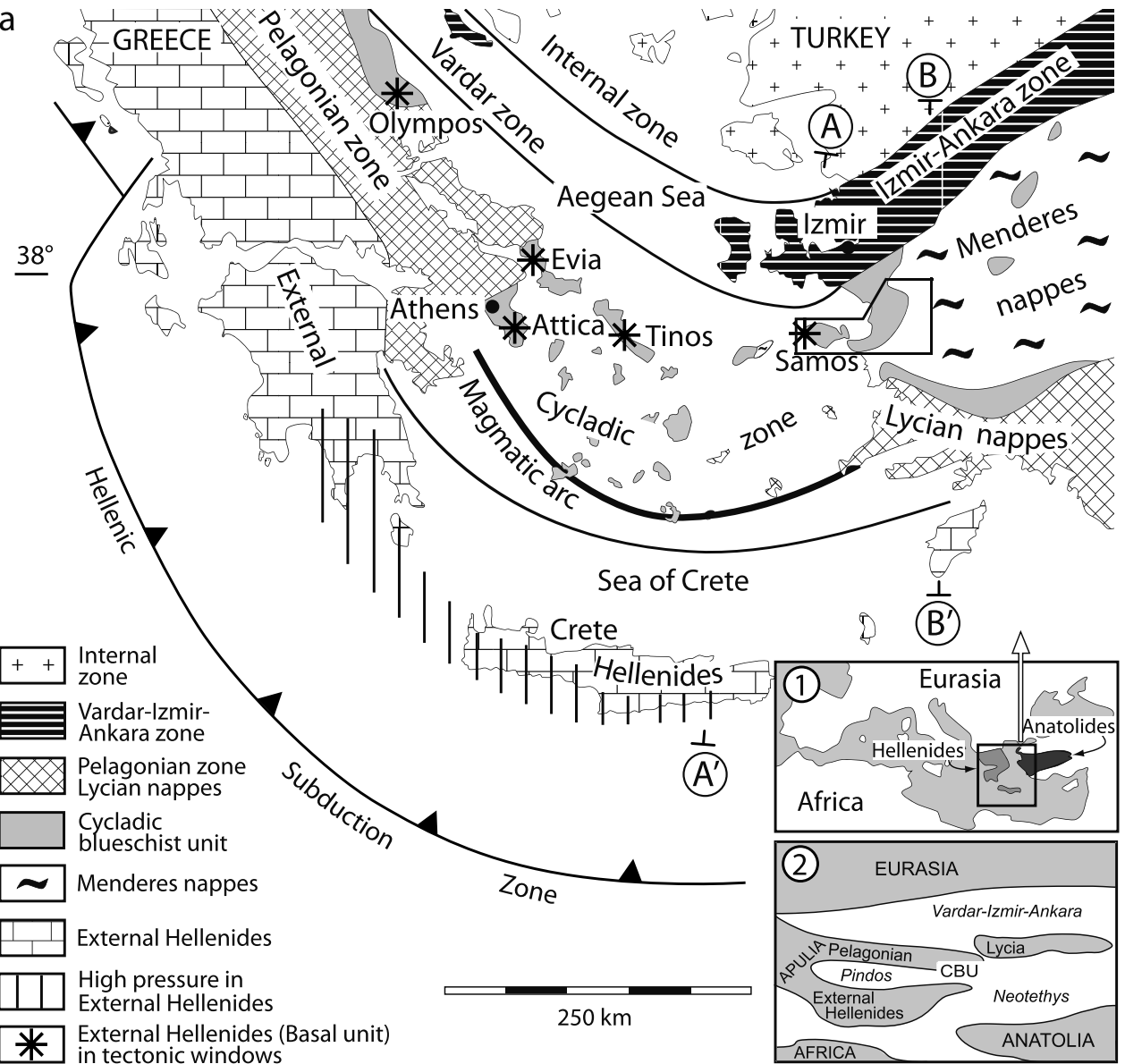

b A

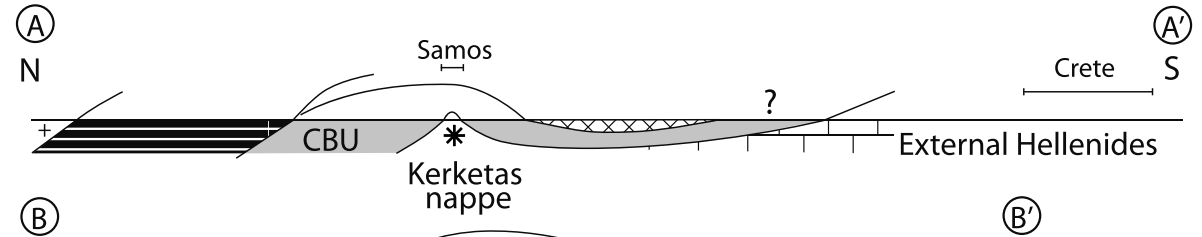

(B)

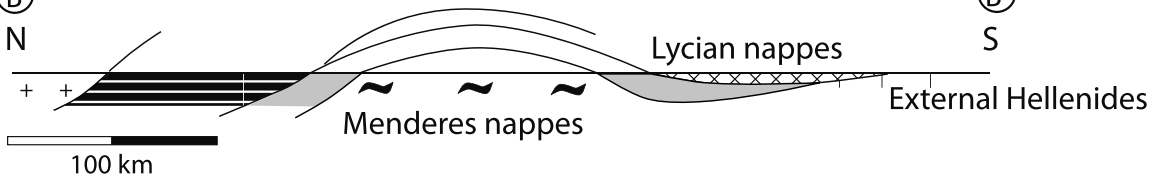

C

\begin{tabular}{|c|c|c|c|c|c|c|c|c|}
\hline \multirow{2}{*}{\multicolumn{2}{|c|}{$\begin{array}{l}\text { Tectonometamorphic unit } \\
\text { and its peak metamorphism }\end{array}$}} & \multicolumn{5}{|c|}{ Epoch } & \multirow{2}{*}{$\begin{array}{r}\text { Time } \\
{[\mathrm{Ma}]}\end{array}$} & \multirow{2}{*}{$\begin{array}{c}\mathrm{P} / \mathrm{T} \\
{\left[\mathrm{kbar} /{ }^{\circ} \mathrm{C}\right]}\end{array}$} \\
\hline & & 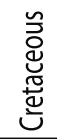 & 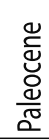 & 这 & 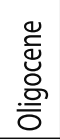 & 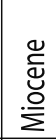 & & \\
\hline & Vardar-Izmir-Ankara zone ${ }^{1}$ & - & & & & & $\sim 80$ & $18-22 / 400-460$ \\
\hline & Lycian nappes $2-4$ & ! & & & & & $\sim 75$ & $7-10 / 300-400$ \\
\hline & Cycladic blueschist unit ${ }^{5,6}$ & & & - & & & $55-45$ & $\begin{array}{l}12-20 / \\
450-550 \\
\end{array}$ \\
\hline * & $\begin{array}{l}\text { External Hellenides in } \\
\text { tectonic windows in } C Z^{7,8}\end{array}$ & & & & & $\boldsymbol{P}$ & $24-21$ & $8-10 / 400$ \\
\hline & HP in External Hellenides ${ }^{9}$ & & & & & 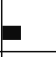 & 24-19 & 8-14/350-450 \\
\hline$\sim$ & Menderes nappes ${ }^{10-16}$ & & & 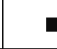 & & & $43-37$ & $4-6 / 400-525$ \\
\hline
\end{tabular}

Figure 2 


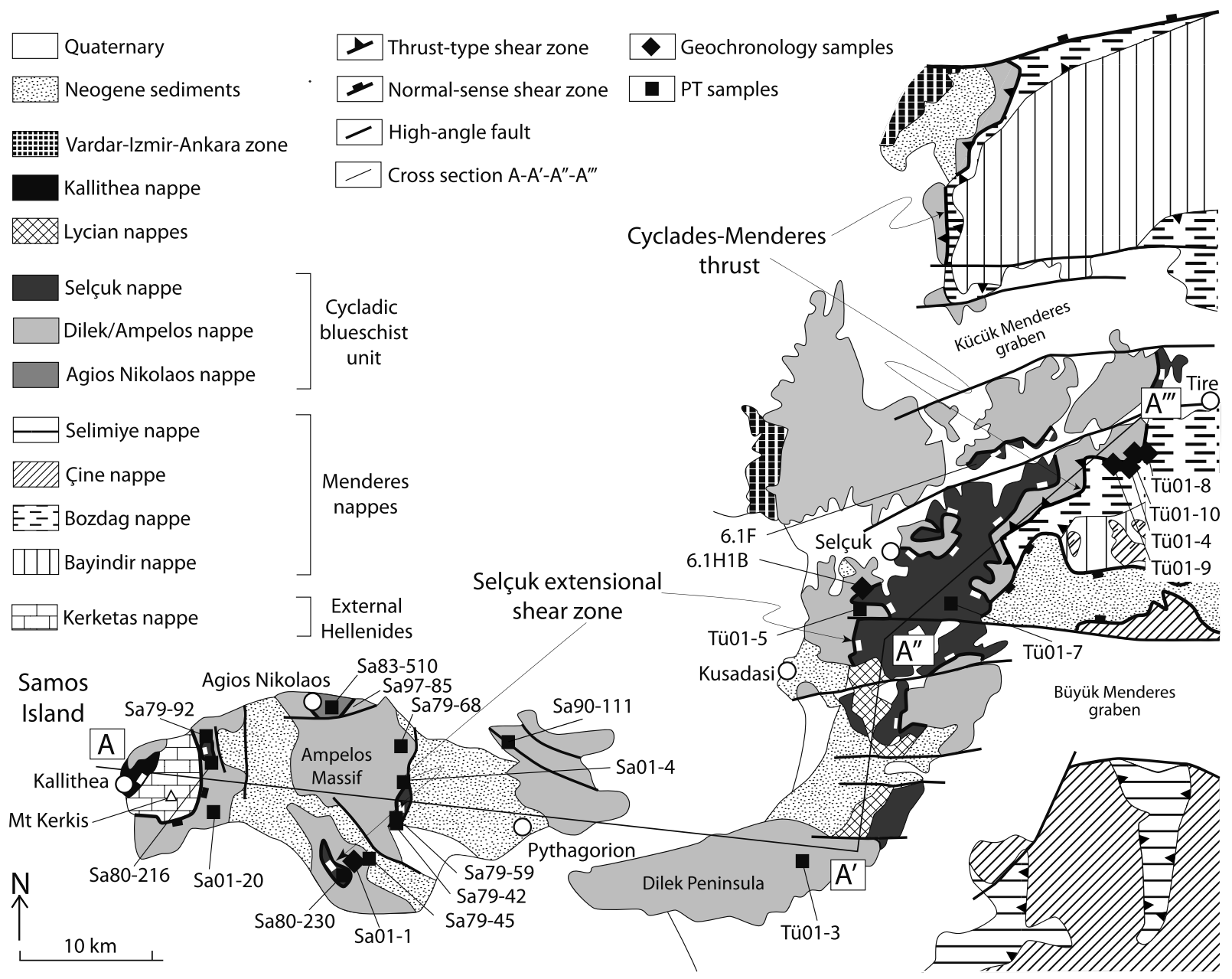

Figure 3. Tectonic map of Samos Island and western Turkey showing various nappes, CycladesMenderes thrust, Selçuk normal shear zone, and samples used for PT and geochronologic work. Note that samples 6.1F and Sa97-85 are structural samples referred to in Figure 6. Position of cross section A-A'$\mathrm{A}^{\prime \prime}-\mathrm{A}^{\prime \prime \prime}$ (Figure 4) is indicated. Note scattered outcrops of Selçuk nappe above and Agios Nikolaos nappe (only exposed on Samos) below Dilek/Ampelos nappe.

Figure 2. (a) Generalized tectonic map of Aegean showing major tectonic units and present-day Hellenic subduction zone. Cycladic blueschist unit is dominant tectonic unit of Cycladic zone in central Aegean and overlain by continental Pelagonian zone/Lycian nappes and oceanic Vardar-İzmir-Ankara suture zone. Basal unit of Cyclades is part of External Hellenides and crops out below Cycladic blueschist unit in some windows (arrows show Olympos and Attica windows on Greek mainland, Almyropotamos and Panormos windows on Evia and Tinos islands and Kerketas nappe on Samos Island). Cycladic blueschist unit and Vardar-İzmir-Ankara zone form high-pressure belts of Cretaceous to Early Tertiary age which span wide area from Greek mainland across northern Aegean Sea into Turkey. Early Miocene high-pressure rocks of External Hellenides occupy more restricted area than older high-pressure rocks and occur south/southeast of late Pliocene to Recent volcanic arc delineated by calc-alkaline volcanoes. In western Turkey, Menderes nappes occur below Cycladic blueschist unit. Menderes nappes have no Tertiary high-pressure overprint. Box indicates location of map shown in Figure 3. Inserts 1, Mediterranean region and location of main map and 2, paleogeographic sketch map for early Cretaceous [after Gessner et al., 2001a] illustrating supposed spatial arrangement of continents and continental fragments. Sketch is schematic and not to scale; CBU, Cycladic blueschist unit. (b) NNE-SSW cross sections showing different nappe piles in eastern Aegean and western Turkey. (c) Tectonometamorphic units in Aegean and western Turkey and their peak metamorphic conditions with approximate age. References (indicated by superscript numbers) 1, Sherlock et al. [1999]; 2, Franz and Okrusch [1992]; 3, Oberhänsli et al. [2001]; 4, Ring and Layer [2003]; 5, Wijbrans et al. [1990]; 6, Tomaschek et al. [2003]; 7, Ring et al. [2001a]; 8, Ring and Reischmann [2002]; 9, Seidel et al. [1982]; 10, Gessner et al. [2001a]; 11, Ring et al. [2001b]; 12, Whitney and Bozkurt [2002]; 13, Régnier et al. [2003]; 14, Lips et al. [2001]; 15, Hetzel and Reischmann [1996]; 16, Catlos and Çemen [2005]. 


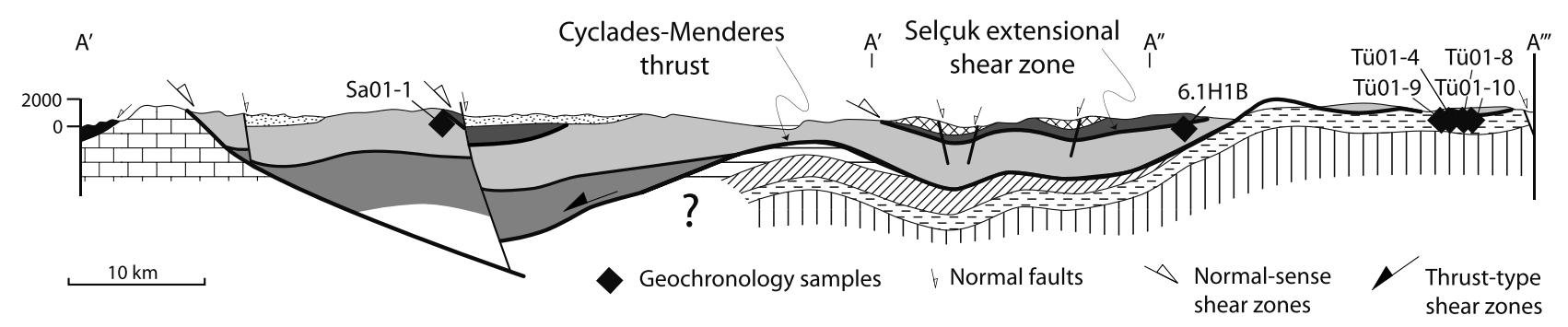

Figure 4. Cross section $A-A^{\prime}-A^{\prime \prime}-A^{\prime \prime \prime}$ showing nappe pile and position of geochronologic samples in Cyclades-Menderes thrust zone and Selçuk normal shear zone. Note that out-of-sequence CycladesMenders thrust cuts across structure of Menderes nappes and that its continuation into Aegean is unconstrained, which also renders position of Menderes nappes relative to Kerketas nappes (as part of External Hellenides) difficult.

[11] In this study we concentrate on a section on Samos Island and the adjacent Turkish mainland (Figures 3 and 4), which provides evidence for considerable Eocene exhumation of the passive-margin sequence of the Cycladic blueschist unit [Gessner et al., 2001a]. In our study area, the Selçuk nappe represents the ophiolitic mélange and contains blocks of metagabbros and garnet-mica schists in a matrix of serpentinites. Across the entire Aegean region, the Selçuk nappe and correlative ophiolitic nappes always have a relatively small thickness and the outcrop pattern is patchy. The passive-margin sequence is represented on Samos Island by the Ampelos nappe and in adjacent western Turkey by the Dilek nappe. The Ampelos/Dilek nappe consists of quartzites, metapelites, metabasite/metaacidite lenses and metabauxite-bearing marbles. The underlying Agios Nikolaos basement nappe on Samos contains metapelites originally intruded by Carboniferous granitoids, now metamorphosed together at high-pressure conditions [Ring et al., 1999b]. Will et al. [1998] showed that PT conditions for high-pressure metamorphism in the basement on Samos were $\sim 3-5 \mathrm{kbar}$ and $\sim 50-80^{\circ} \mathrm{C}$ higher than in the passive-margin sequence, indicating that both units were tectonically separated.

\section{Analytical Methods, Sample Descriptions, PT, and Geochronologic Results}

\subsection{Petrography of Samples Used for Thermobarometry}

[12] Rocks from the Ampelos/Dilek nappe and the Selçuk nappe (Figure 3) were collected for constraining the PT conditions of high-pressure assemblages and of retrogression in ductile shear zones. The mineral chemical data on which the PT calculations are based are given in Table A1 in Appendix A and the PT results are given in Table 1. Some selected samples are described below.

[13] Metagabbroic samples from the Selçuk nappe are usually massive, sodic amphibole-bearing rocks (Sa79-68, 79-92, Sa80-216). In some samples, omphacitic pyroxene occurs as well (Sa79-42, Sa79-45, Sa80-230). Garnet-bearing amphibolites (Tü01-7) occur in the Selçuk nappe in western Turkey. Strongly mylonitized metagabbros from the Selçuk normal shear zone (Figures 3 and 4) (Sa79-59, Sa01-4) contain sodic amphibole and diopsidic pyroxene, but lack omphacite.

[14] Samples Sa79-92 and Sa80-216 are massive glaucophane-bearing metagabbros that do not contain omphacite. The major minerals are sodic and calcic amphiboles, epidote, albite and chlorite. In addition, various amounts of biotite, titanite, magnetite, ilmenite, and traces of white mica occur. The rocks have a coarse-grained, relic magmatic texture, which was modified during metamorphism. The metamorphic mineral assemblage sodic amphibole-epidotewhite mica is ascribed to blueschist-facies metamorphic conditions, and the assemblage calcic to barroisitic amphibole-epidote-chlorite-albite to a subsequent decompression stage. The $\mathrm{X}_{\mathrm{Mg}}=\mathrm{Mg} /\left(\mathrm{Mg}+\mathrm{Fe}^{2+}\right)$ values of all amphiboles range between 0.50 and 0.62. Sample Sa79-92 contains actinolite and $\mathrm{Mg}$-Al-hornblende $\left(\mathrm{X}_{\mathrm{Mg}} \approx 0.5-\right.$ 0.7), which does not occur in sample Sa80-216. Epidote has pistacite values $\left(\mathrm{X}_{\mathrm{Ps}}=\mathrm{Fe}^{3+} /\left(\mathrm{Fe}^{3+}+\mathrm{Al}^{[6]}\right)\right)$ of 0.21 to 0.33 ; chlorite has uniform $\mathrm{X}_{\mathrm{Mg}}$ values of $0.44-0.47$.

[15] Samples Sa80-230, Sa79-42, and Sa79-45 are massive omphacite-bearing metagabbros that also preserve highpressure assemblages. The samples contain green and colorless hornblende, diopsidic and omphacitic pyroxene, epidote, chlorite, albite, quartz, and accessory titanite. The samples have a relic magmatic, massive texture: large, anhedral magmatic green hornblende is rimmed by pale green to colorless actinolite and actinolite-chlorite \pm titanite intergrowths. Magmatic clinopyroxene is rimmed by green hornblende and, in places, replaced by colorless chlorite. Plagioclase occurs both as large poikiloblasts containing fine-grained actinolite, chlorite, and epidote and as finegrained recrystallized minerals. Compositionally, the amphiboles range from almost pure actinolite to $\mathrm{Mg}$-hornblende, with $\mathrm{X}_{\mathrm{Mg}}$ values between 0.75 and 0.85 . Ca-pyroxene is a diopside-dominated solid solution of $63-75 \mathrm{~mol} \%$ diopside, $17-21 \mathrm{~mol} \%$ hedenbergite, and 2-10 mol \% enstatite and has $\mathrm{X}_{\mathrm{Mg}}$ values of $\sim 0.80$. Na-pyroxene has up to $9.5 \mathrm{wt} \%$ $\mathrm{Na}_{2} \mathrm{O}$ and forms a solid solution of $31-52 \mathrm{~mol} \%$ jadeite, 
Table 1. PT Conditions for Samples From Samos Island and Western Turkey ${ }^{\mathrm{a}}$

\begin{tabular}{|c|c|c|c|c|c|c|c|}
\hline Sample (Unit) & Rock Type & Assemblage & $\mathrm{P}$, kbar & $2 \sigma(\mathrm{P})$ & $\mathrm{T},{ }^{\circ} \mathrm{C}$ & $2 \sigma(\mathrm{T})$ & $\chi^{2}$ \\
\hline Sa79-92 (SN) & $\begin{array}{l}\text { massive, nam-bearing } \\
\text { metagabbro }\end{array}$ & barr am-ep-chl-ab-q & 7.9 & 2.2 & 482 & 40 & $0.57(1.96)$ \\
\hline $\mathrm{Sa} 80-216(\mathrm{SN})$ & $\begin{array}{l}\text { massive, nam-bearing } \\
\text { metagabbro }\end{array}$ & barr am-ep-chl-ab-mt-q & 8.0 & 1.4 & 411 & 43 & $1.42(1.61)$ \\
\hline $\mathrm{Sa} 80-230(\mathrm{SN})$ & $\begin{array}{l}\text { massive, omp-bearing } \\
\text { metagabbro }\end{array}$ & $\begin{array}{l}\text { cam-ep-chl-ab-q } \\
\text { omp-parg hb-chl-ep } \\
\text { jd barometer }\end{array}$ & $\begin{array}{l}2.9 \\
8.0 \\
11.3\left(\text { for } \mathrm{T}=500^{\circ} \mathrm{C}\right) \\
10.6\left(\text { for } \mathrm{T}=450{ }^{\circ} \mathrm{C}\right)\end{array}$ & 1.41 .3 & 424430 & 3335 & $\begin{array}{l}1.26(1.61) \\
\quad 1.26(1.54)\end{array}$ \\
\hline $\mathrm{Sa} 79-42(\mathrm{SN})$ & $\begin{array}{l}\text { massive, omp-bearing } \\
\text { metagabbro }\end{array}$ & jd barometer; law ${ }^{\mathrm{b}}$ & $\begin{array}{l}11.9\left(\text { for } \mathrm{T}=500^{\circ} \mathrm{C}\right) \\
10.8\left(\text { for } \mathrm{T}=450^{\circ} \mathrm{C}\right)\end{array}$ & & & & \\
\hline $\mathrm{Sa} 79-45(\mathrm{SN})$ & $\begin{array}{l}\text { massive, omp-bearing } \\
\text { metagabbro }\end{array}$ & jd barometer & $\begin{array}{l}11.8\left(\text { for } \mathrm{T}=500^{\circ} \mathrm{C}\right) \\
10.9\left(\text { for } \mathrm{T}=450^{\circ} \mathrm{C}\right)\end{array}$ & & & & \\
\hline Sa79-59 (SN) & $\begin{array}{l}\text { mylonitized, di-bearing } \\
\text { metagabbro }\end{array}$ & barr am-ep-chl-ab-q & 4.0 & 1.6 & 454 & 42 & $1.35(1.73)$ \\
\hline Sa79-68 (SN) & $\begin{array}{l}\text { massive, nam-bearing } \\
\text { metagabbro }\end{array}$ & barr am-ep-chl-ab-mu & 4.0 & 1.1 & 439 & 37 & $0.57(1.73)$ \\
\hline $\mathrm{Sa} 01-4 b(\mathrm{SN})$ & $\begin{array}{l}\text { mylonitized, di-bearing } \\
\text { metagabbro }\end{array}$ & barr am-ep-chl-ab-q & 2.6 & 1.1 & 437 & 21 & $0.81(1.61)$ \\
\hline Sa 01-20 (AD) & metapelitic schist & ctd-ky-pa-zo-q & $\begin{array}{l}\mathrm{P}_{\min } \sim 11^{\mathrm{c}} \\
\quad\left(\text { for } \mathrm{T}=500^{\circ} \mathrm{C}\right)\end{array}$ & & & & \\
\hline Tü01-7 (SN) & grt-bearing amphibolite & g-cam-ep-chl-qtz-nam ${ }^{\mathrm{d}}$ & 12.4 & 1.2 & 550 & 18 & $1.17(1.61)$ \\
\hline Tü01-3 (AD) & metapelitic schist & ctd-ky-chl-mu-q & 5.4 & 1.4 & 500 & 26 & $0.96(1.73)$ \\
\hline Tü01-5 (AD) & metapelitic schist & ctd-ky-chl-mu-q & 9.3 & 2.4 & 544 & 62 & $1.62(1.73)$ \\
\hline & & & 10.2 & 2.8 & 528 & 55 & $1.53(1.73)$ \\
\hline Sa90-111 (AD) & metapelitic schist & ctd-pa-ky-chl-q & $\sim 15^{\mathrm{e}}$ & & $500^{\mathrm{e}}$ & & \\
\hline $\mathrm{Sa} 83-510(\mathrm{AN})$ & grt-bearing glaucophanite & nam-g-pa-zo-chl-law ${ }^{\mathrm{b}}-\mathrm{q}$ & $\sim 18-19^{\mathrm{e}}$ & & $530^{\mathrm{e}}$ & & \\
\hline
\end{tabular}

${ }^{a}$ Results of $\chi^{2}$ test are given; test is passed if calculated number is smaller than cutoff value given in parentheses. Mineral abbreviations are after Holland and Powell [1998], except for omp, omphacitic Na-pyroxene; nam, Na-amphibole; cam, Ca-amphibole; jd, jadeite; barr am, barroisitic amphibole; parg hb, pargasitic hornblende; unit abbreviations SN, Selçuk nappe; AD, Ampelos/Dilek nappe; AN, Agios Nikolaos nappe. Sa, Samos Island; Tü, western Turkey.

${ }^{\mathrm{b}}$ Law, pseudomorphs after lawsonite.

${ }^{c}$ For phase petrological constraints [Will et al., 1998].

${ }^{\mathrm{d}} \mathrm{Nam}$, as inclusion in garnet.

${ }^{\mathrm{e}}$ For details, see Will et al. [1998].

9-25 mol \% acmite, 30-54 mol \% diopside, and 1-7 mol \% hedenbergite. $\mathrm{X}_{\mathrm{Mg}}$ varies between 0.87 and 0.95 . The pistacite component in epidote ranges from 0.17 to 0.24 , and chlorite has $\mathrm{X}_{\mathrm{Mg}}$ values between 0.68 and 0.83 . In sample Sa79-42, pseudomorphs after lawsonite are present.

[16] Samples Sa79-59 and Sa01-4 are strongly mylonitized metagabbros that contain relics of magmatic diopsidic pyroxene and brown, Ti-bearing amphibole. Furthermore green-blue and colorless amphibole, chlorite, albite, epidote and quartz are present. Accessory titanite, biotite and opaque phases, which are generally transformed to leucoxene, occur. The green-blue amphibole is barroisitic to tschermakitic in composition, the colorless to light green amphiboles are actinolites and $\mathrm{Mg}$ hornblendes. The $\mathrm{X}_{\mathrm{Mg}}$ values of all amphiboles lie between 0.6 and 0.8 . The pistacite component in epidote ranges between 13 and $31 \mathrm{~mol} \%$, chlorite has uniform $\mathrm{X}_{\mathrm{Mg}}$ values of $0.57-0.59$.

[17] The garnet-amphibolite Tü01-7 contains Mn-rich garnet (up to $6.3 \mathrm{wt} \%$ in its cores) set in a very fine grained, crenulated matrix of actinolite, hornblende, chlorite, epidote, biotite and plagioclase. The garnet rims are replaced by chlorite and biotite. Glaucophane, rutile, epidote, ilmenite and quartz occur as inclusions in garnet and form straight inclusion bands.
[18] Metapelitic rocks from the Ampelos/Dilek nappe are strongly foliated, fine-grained rocks that contain kyanite and large chloritoid porphyroblasts (Sa90-111, Sa01-20, Tü01-3, Tü01-5). In the underlying Agios Nikolaos nappe garnetbearing glaucophanites (Sa83-510) occur. For a description of samples Sa83-510 and Sa90-111, see Will et al. [1998].

[19] Samples Sa01-20, Tü01-3, and Tü01-5 are strongly foliated metapelitic schists. Tü01-3 and Tü01-5 contain poikiloblastic and, in places, twinned kyanite. Furthermore, up to $0.6 \mathrm{~mm}$ large (in diameter) twinned chloritoid poikiloblasts occur in a fine-grained matrix of quartz, white mica and minor chlorite. The foliation is defined by white mica and a shape preferred orientation of quartz. The foliation wraps around chloritoid. Inclusions in chloritoid are plagioclase, quartz, opaques and white mica. Locally, the kyanite crystals exhibit undulose extinction, commonly they are surrounded by quartz-filled strain shadows and contain plagioclase and quartz inclusions. Chloritoid is a Fe-MgMn solid solution with 43-54 mol \% Mg-chloritoid, 22$33 \mathrm{~mol} \%$ Fe-chloritoid, and 17-30 mol \% Mn-chloritoid. Chlorite is very $\mathrm{Mg}$-rich with $\mathrm{X}_{\mathrm{Mg}}=\mathrm{Mg} /\left(\mathrm{Mg}+\mathrm{Fe}^{2+}+\mathrm{Mn}\right)$ values of $0.81-0.88$. Both, muscovite and paragonite are present. Muscovite has 3.06 to $3.13 \mathrm{Si}$ per formula unit (pfu) (for 11 oxygens) and contains $14-18 \mathrm{~mol} \%$ para- 

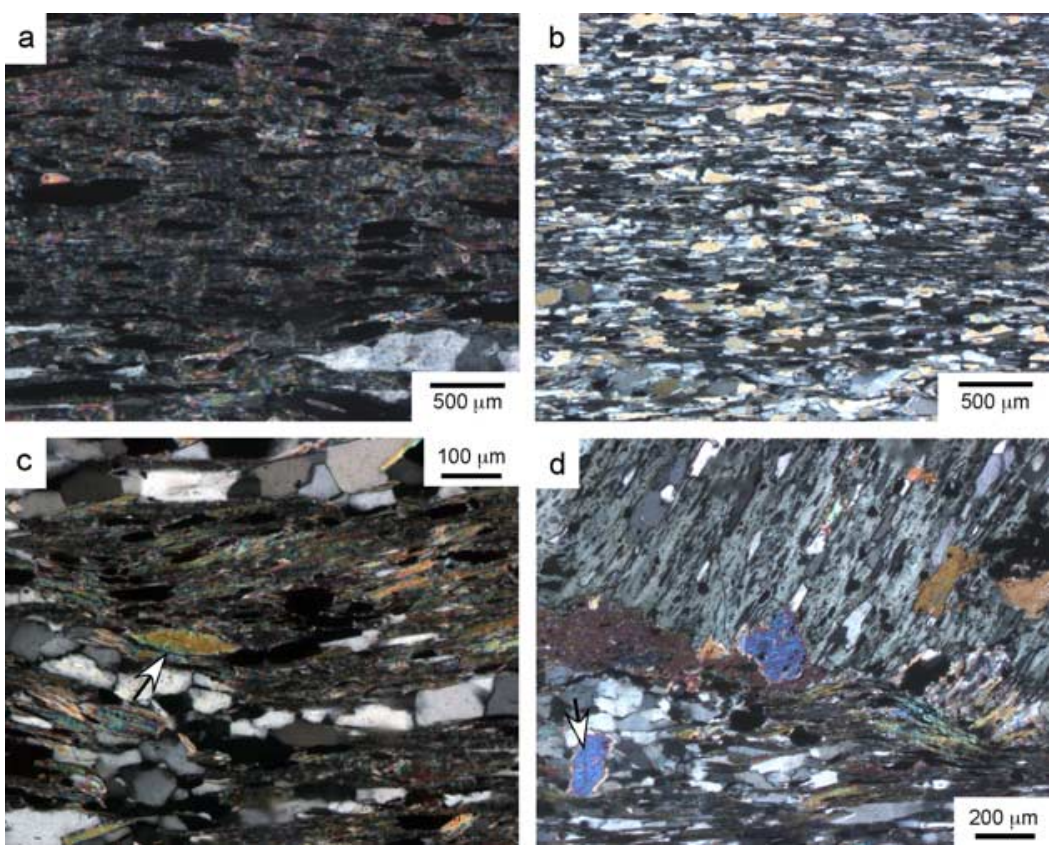

Figure 5. Microphotographs of samples used for geochronologic work. (a) Strongly sheared white mica with opaques in mylonitic foliation from Cyclades-Menderes thrust, sample Tü01-10. (b) Mylonitic foliation consisting of white mica and quartz, sample 6.1H1B from Selçuk normal shear zone. (c) Mylonitic white mica-quartz foliation in sample Sa01-1 from Selçuk normal shear zone. Note relic white mica grains (arrow) between layers of strongly recrystallized white mica. (d) Mylonitic white micaquartz foliation in chloritoid-kyanite quartzite from Selçuk normal shear zone in south of Selçuk. Note relic relatively large phengite crystals (arrow) close to large rotated chloritoid; sample 6.1H1B. Refer to Figure 3 for sample localities.

gonite. The Na-mica is almost pure paragonite with $\mathrm{X}_{\mathrm{Pa}}$ $(=\mathrm{Na} /(\mathrm{Na}+\mathrm{K})$ of $\sim 0.98$ and $2.97-2.99$ Si pfu. In sample Sa01-20 the foliation is formed by aligned chloritoid, zoisite and white mica and a shape preferred orientation of quartz. Chloritoid is almost completely $\mathrm{Mn}$-free and contains 37-39 mol \% Mg-chloritoid and 59-60 mol \% Fe-chloritoid. Muscovite and paragonite occur. Muscovite has 3.06-3.09 Si pfu with $17-21 \mathrm{~mol} \%$ of the paragonite end-member. Paragonite has $\mathrm{X}_{\mathrm{Pa}}$ values of $0.86-0.95$ and 2.92-3.00 Si pfu. Zoisite has uniform $\mathrm{X}_{\mathrm{Ps}}$ values of $0.22-0.25$.

\subsection{Pressure-Temperature Analysis}

[20] PT conditions of formation of peak metamorphic parageneses within the Ampelos/Dilek and Selçuk nappes and mylonitic mineral assemblages at the upper and lower contacts of the Ampelos/Dilek nappe were calculated, assuming local equilibria, using the average PT method of Powell and Holland [1994] and an updated version (May 2001 data) of the thermodynamic data set of Holland and Powell [1998]. Once the end-members of the minerals in an equilibrium assemblage are distinguished, it is possible to balance all the reactions among those end-members. With the thermodynamic data available, each reaction can be used to calculate the PT conditions of formation of the assemblage. Average PT estimates can be calculated from a linearly independent set of end-member reactions. For example, five independent reactions can be balanced for the assemblage barroisitic hornblende-epidote-chloriteplagioclase-chlorite-quartz- $\mathrm{H}_{2} \mathrm{O}$. The calculated pressures and temperatures are correlated and the best average PT value is obtained by least squares techniques, allowing to determine standard deviations on the results. Additionally, a $\chi^{2}$ test is applied to the average PT result to check the reliability of the estimate. For example, for five independent reactions, the $\chi^{2}$ value should be $<1$.6. In all our calculations this test was passed (Table 1), which indicates the reliability of the results and our initial assumption of local equilibrium. The results including the standard deviations are summarized in Table 1. This approach was augmented by the application of the jadeite-albite-quartz geobarometer (calibration after Holland [1980]) to the omphacite-bearing samples Sa79-45 and Sa80-230. The activities of the mineral end-members in the solid solutions were calculated with the program ax (http://www.esc.cam.ac.uk/astaff/holland/ ax.html).

\subsection{Pressure-Temperature Estimates}

[21] The results of the PT estimations are summarized in Table 1. Garnet amphibolite sample Tü01-7 from the central Selçuk nappe yielded well-constrained PT conditions of 
$\mathrm{N}$
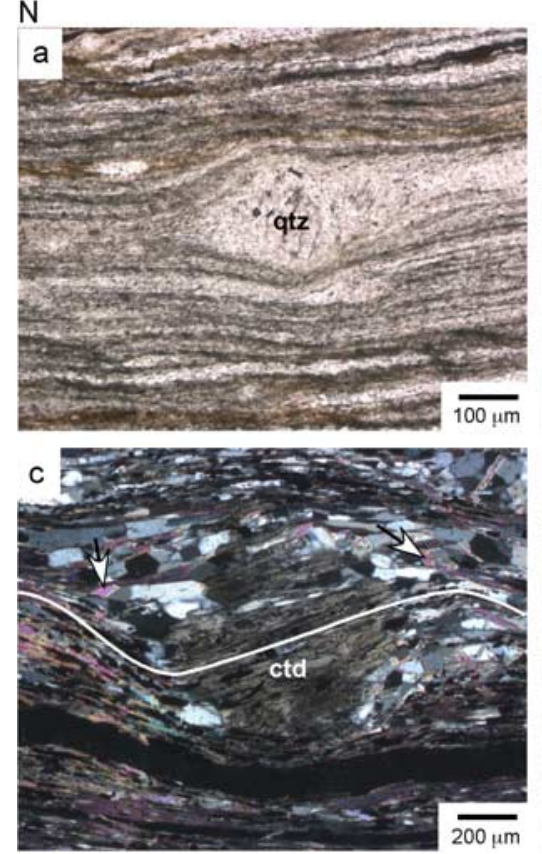
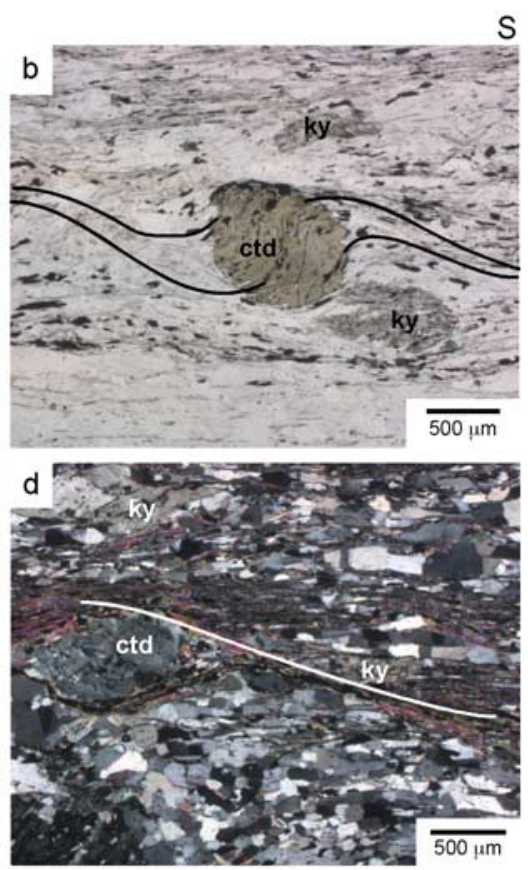

Figure 6. Microphotographs of deformation structures at base and top of Ameplos/Dilek nappe. (a) Strongly chloritized mylonitic foliation from Cyclades-Menderes thrust southwest of Tire. Asymmetric quartz porphyroclasts indicates top-to-the-south sense of shear; sample Tü01-9. (b) Rotated synkinematic chloritoid (ctd) with $\delta$-type asymmetric strain shadows indicating top-to-the-NE sense of shear from Selçuk normal shear zone south of Selçuk; sample 6.1H1B; ky, kyanite. (c) Rotated chloritoid in sample 6.1F indicating top-to-the-NE shear sense. Note relic white mica grains (arrow) between layers of strongly recrystallized white mica. (d) Shear band in chloritoid-kyanite schist from basal parts of Ampelos/Dilek nappe indicating top-to-the-SE shear sense; sample Sa97-85. Refer to Figure 3 for sample localities.

$550 \pm 18^{\circ} \mathrm{C}$ and $12.4 \pm 1.2 \mathrm{kbar}$, which we consider to reflect maximum PT in the Selçuk nappe.

[22] In metagabbros from the basal Selçuk nappe, calculations were carried out on mineral assemblages containing barroisitic hornblende, epidote/zoisite, plagioclase and chlorite \pm quartz. Clearly, this is an assemblage transitional between the middle/upper greenschist and lower blueschist facies. Maximum PT conditions of the high-pressure stage for metagabbros from the basal Selçuk nappe in Samos are of the order of $8-12 \mathrm{kbar}$ and $400-500^{\circ} \mathrm{C}$. Mylonitic deformation during greenschist-facies retrogression occurred at $3-5 \mathrm{kbar}$ and $420-440^{\circ} \mathrm{C}$.

[23] The chloritoid-kyanite schists at the top of the Ampelos/Dilek nappe yielded varying PT estimates ranging from $\sim 15 \mathrm{kbar}$ and $\sim 500^{\circ} \mathrm{C}$ (sample Sa90-111) to $5.4 \pm$ $1.4 \mathrm{kbar}$ and $500 \pm 26^{\circ} \mathrm{C}$ (sample Tü01-3). Other samples yielded intermediate pressures of some 9-10 $\pm 2.5 \mathrm{kbar}$ at similar temperatures of $\sim 500^{\circ} \mathrm{C}$ (Table 1).

[24] No reliable PT estimates could be obtained from the strongly chloritized mylonite at the Cyclades-Menderes thrust. However, the fact that biotite is not stable in the mylonite anymore (see below) and pressures of 4-6 kbar in the rocks of the Menderes nappes below the thrust strongly suggest PT conditions of $<4-6 \mathrm{kbar}$ and $<400^{\circ} \mathrm{C}$ in the mylonite. These PT estimates are largely similar to those from the mylonitic metagabbros at the base of the Selçuk nappe.

\subsection{Description of Geochronology Samples}

[25] Samples Tü01-4, Tü01-8, Tü01-9, and Tü01-10 from the Cyclades-Menderes thrust (Figure 3) are all quartzdominated mylonites (Figures 5a and 6a), with white mica and accessory apatite, feldspar, chloritized biotite, zircon and rutile. White mica is phengitic/muscovitic in composition with Si values of 3.01-3.38 pfu (Figure 7a).

[26] Samples Sa01-1 and 6.1H1B are from the Selçuk normal shear zone (Figure 3). Both are similarly quartzdominated mylonites (Figure 5b), with white mica, stretched kyanite laths and rotated chloritoid (Figure 6b), as well as accessory feldspar, zircon, ilmenite, rutile and tourmaline. White mica is phengitic/muscovitic in composition with $\mathrm{Si}$ values of 3.03-3.27 pfu (Figure 7b). The individual white mica crystals are again homogeneous in composition (Figures 8b, 9b, and 9c). However, sample Sa01-1 has paragonite as well, and in some cases detectable intergrowths of phengite and paragonite were observed in this sample. 


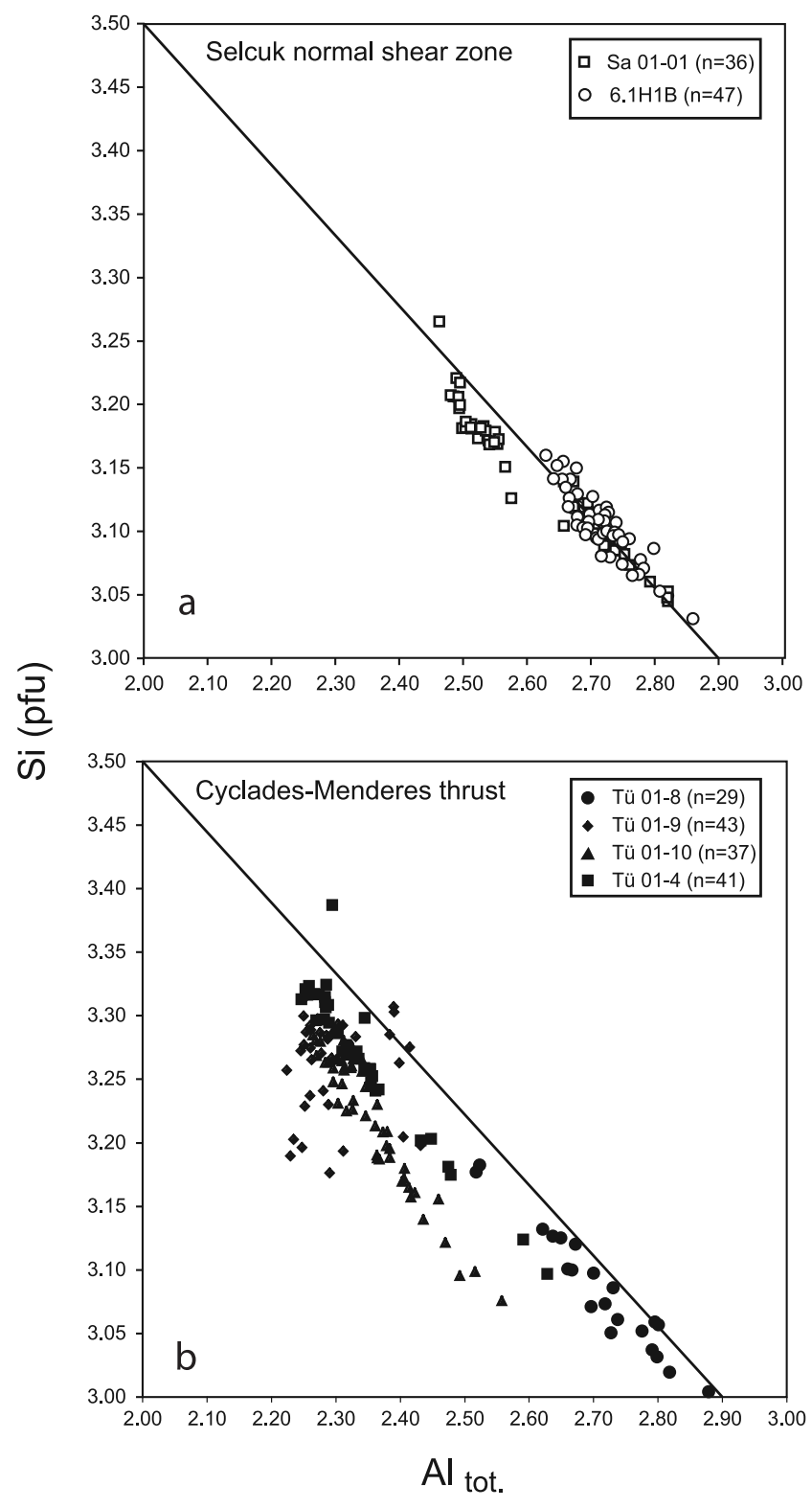

Figure 7. $\mathrm{Si}$ versus $\mathrm{Al}_{\text {tot }}$ plots for white mica from mylonites from (a) Cyclades-Menders thrust and (b) Selçuk normal shear zone. Line corresponds to ideal muscovite/ celadonite join.

[27] All samples are extensively dynamically recrystallized and no obvious feldspar textural relics are observed (Figures $5 \mathrm{a}-5 \mathrm{~d}$ ). The very strong mylonitization caused complete recrystallization of white mica, feldspar, apatite and other minerals and only one single phase of a mineral is present in each dated sample. X-ray mapping shows that individual white mica grains are largely unzoned with respect to $\mathrm{Al}, \mathrm{Fe}, \mathrm{Mg}$ and $\mathrm{K}$ (Figure 8). Compositional traverses across single white mica crystals depict no absolute variations in Si content (Figure 9). The element distribution maps and the traverses attest to the homogene- ity of the crystals. Although individual white mica crystals in the dated samples are homogeneous, the grains show a relatively large scatter in $\mathrm{Si}$ values from crystal to crystal, which reflects different conditions and stages of recrystallization (Figures $5 \mathrm{c}$ and $5 \mathrm{~d}$ ). The only exception to the chemical homogeneity of single grains are a few relic, nonrecrystallized white mica crystals in sample Sa01-1 (Figure 5c), which show subtle phengite/paragonite intergrowths. These "old" grains survived between strongly sheared and recrystallized white mica layers (Figure 5c).

[28] For $\mathrm{Rb}-\mathrm{Sr}$ and ${ }^{40} \mathrm{Ar}^{39} \mathrm{Ar}$ step-heating dating we analyzed separated minerals from pervasively deformed, $5 \mathrm{~cm}^{3}$-sized domains. For ${ }^{40} \mathrm{Ar}-{ }^{39} \mathrm{Ar}$ spot fusion laser dating we analyzed phengite domains that have different $\mathrm{Si}$ values.

\subsection{Analytical Procedures for Geochronology}

[29] For $\mathrm{Rb}-\mathrm{Sr}$ analysis the internal mineral isochron approach was used. Small samples $(\sim 20-100 \mathrm{~g})$ have been chosen which are extremely strongly deformed and show a minimum of postmetamorphic alteration. To detect possible Sr-isotopic inhomogeneities in the mylonitic rocks, resulting from incomplete or protracted dynamic recrystallization, from diffusional $\mathrm{Sr}$ redistribution and/or from alteration processes, white mica was usually analyzed in several, physically different (by magnetic properties and/or grain size) fractions. White mica fractions were ground in ethanol in an agate mortar and then sieved in ethanol to obtain inclusion free separates. All mineral concentrates were checked and finally purified by handpicking under a binocular microscope. $\mathrm{Rb}$ and $\mathrm{Sr}$ concentrations were determined by isotope dilution using mixed ${ }^{87} \mathrm{Rb}^{8}{ }^{84} \mathrm{Sr}$ spikes. Determinations of $\mathrm{Rb}$ and $\mathrm{Sr}$ isotope ratios were carried out on a VG Sector 54 multicollector TIMS instrument (GeoForschungsZentrum Potsdam). Sr was analyzed in dynamic mode. The value obtained for ${ }^{87} \mathrm{Sr}-{ }^{86} \mathrm{Sr}$ of the National Bureau of Standards (NBS) standard SRM 987 was $0.710268 \pm 0.000015(\mathrm{n}=19)$. The observed ratios of $\mathrm{Rb}$ analyses were corrected for $0.25 \%$ per amu mass fractionation. Total procedural blanks were consistently below $0.15 \mathrm{ng}$ for both $\mathrm{Rb}$ and $\mathrm{Sr}$. Because of highly variable blank values, no useful blank correction was applicable. Isochron parameters were calculated using the Isoplot/Ex program of Ludwig [1999]. Standard errors, as derived from replicate analyses of spiked white mica samples, of $\pm 0.005 \%$ for ${ }^{87} \mathrm{Sr}^{86} \mathrm{Sr}$ ratios and of $\pm 1.5 \%$ for $\mathrm{Rb}$-Sr ratios were applied in isochron age calculations. Individual analytical errors were generally smaller than these values.

[30] For $^{40} \mathrm{Ar}^{39}{ }^{39} \mathrm{Ar}$ dating, white mica was degassed with an argon laser probe using step heating or direct ablation of grains on rock thin sections. For step-heating analyses, single grains less than $1 \mathrm{~mm}$ in diameter were progressively degassed with a defocused argon laser beam until their fusion. An apparent age was calculated for each heating step and reported within an age spectrum where the successive ages are plotted against the cumulative amount of argon released. The data were also evaluated in ${ }^{36} \mathrm{Ar} /{ }^{40} \mathrm{Ar}$ versus ${ }^{39} \mathrm{Ar} /{ }^{40} \mathrm{Ar}$ correlation plots for which intercepts with the abscissa and ordinate axes correlate with age and ${ }^{40} \mathrm{Ar}-{ }^{39} \mathrm{Ar}$ initial ratio. The ${ }^{40} \mathrm{Ar}^{-39} \mathrm{Ar}$ laser probe dating has been also 

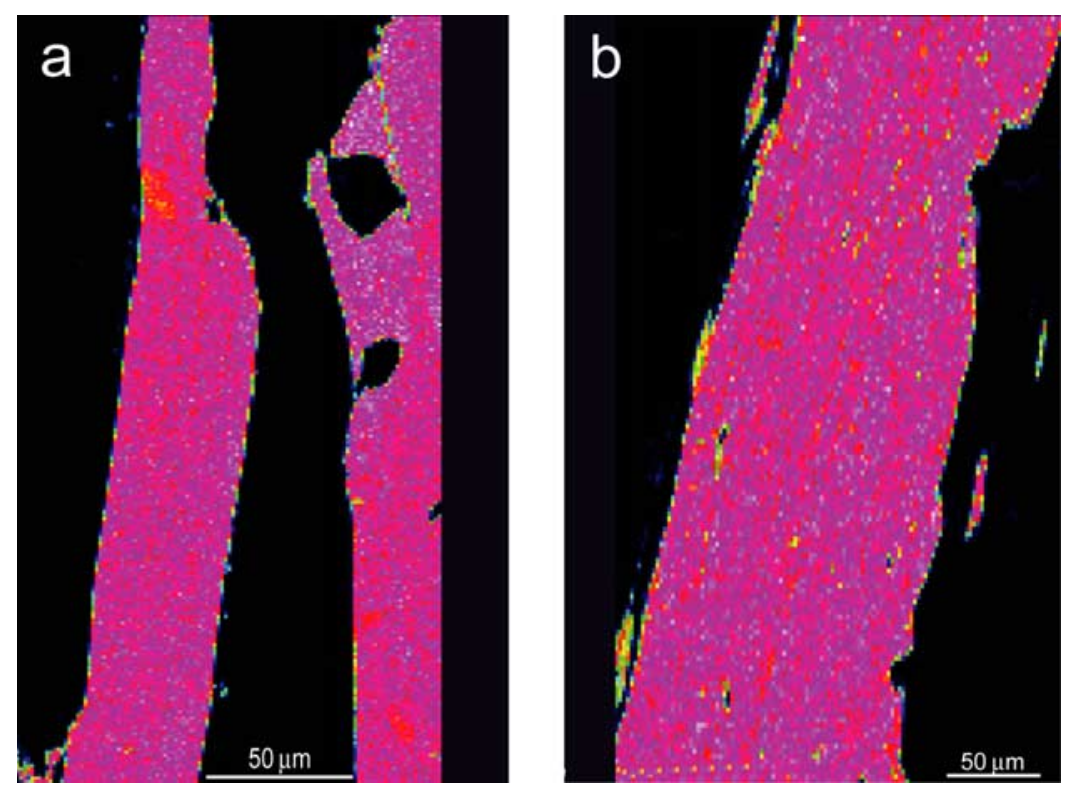

Figure 8. X-ray maps showing aluminum distribution in (a) white mica from sample Tü01-10 and (b) white mica from sample $6.1 \mathrm{H} 1 \mathrm{~B}$, color code from high to low concentration: purple-red-orangeyellow-green-blue-black. Distribution is largely homogeneous. Very fine Al-depleted rims developed along grain boundaries.

applied to sections $(\sim 10.5 \mathrm{~cm})$, which were polished on one side and afterward cleaned in ethanol and distilled water. Both single grains and rock sections were packed in aluminum foils and irradiated for 70 hours in the McMaster nuclear reactor (Canada) together with the $\mathrm{MMHb}$ hornblende neutron flux monitor dated at $520.4 \pm 1.7 \mathrm{Ma}$ [Samson and Alexander, 1987]. After irradiation, the samples were placed on a $\mathrm{Cu}$ holder inside an ultrahigh-vacuum gas extraction system and baked for 48 hours at $200^{\circ} \mathrm{C}$. For step-heating analyses, the progressive degassing of each single grain includes $40 \mathrm{~s}$ of laser exposure at variable beam power and $5 \mathrm{~min}$ of gas cleaning. For in situ spot ablation of mica in thin section, several spots (10 to 20) were performed on the mineral surface with a focused laser beam using an exposure time of $30 \mathrm{~ms}$ for each spot. Each crater is a $30-40 \mu \mathrm{m}$ pit surrounded by a wall of melted material. After gas extraction and cleaning, Ar is introduced into the mass spectrometer and $15 \mathrm{~min}$ are required for data acquisition by peak switching from mass 40 to 36, through 10 sets of data. System blanks were evaluated every three analyses and range around $2 \times 10^{-12} \mathrm{~cm}^{3}$ for ${ }^{40} \mathrm{Ar}$ and $3 \times$ $10^{-14} \mathrm{~cm}^{3}$ for ${ }^{36} \mathrm{Ar}$. For each analysis, classical isotope corrections including blanks, mass discrimination radioactive decay of ${ }^{37} \mathrm{Ar}$ and ${ }^{39} \mathrm{Ar}$ and irradiation-induced mass interferences were applied to calculate the variable argon ratios. Step heating and spot fusion apparent ages were calculated assuming that all the initially trapped argon was atmospheric in composition.

[31] For fission track dating, apatite crystals were separated, mounted, polished and etched according to the techniques outlined by Hurford [1990]. The samples were analyzed applying the external detector method and irradiated at the Oregon State University Triga Reactor, Corvallis, USA. The neutron fluence was monitored using Corning uranium-dosed glass CN5. Spontaneous and induced fission track densities were counted using a Zeiss Axioplan microscope at 1250 times magnification. A CN5 apatite zeta calibration factor of $130.7 \pm 2.8 \mathrm{Ma}$ was obtained by repeated calibration against a number of internationally agreed age standards according to the recommendations of Hurford [1990]. For samples that have undergone moderate to fast cooling, a value of $100 \pm 20^{\circ} \mathrm{C}$ can reasonably be assumed for the closure temperature of fission tracks in apatite [Green et al., 1989].

\subsection{Geochronology of Mylonites: Deformation or Cooling Ages?}

[32] A crucial question in geochronology of mylonites is whether isotopic closure of the dated minerals was related to the cessation of dynamic recrystallization, or due to cooling below a "closure temperature," i.e., whether the ages are deformation or cooling ages. The Rb-Sr system of muscovitic and phengitic white mica is thermally stable to temperatures $>500-550^{\circ} \mathrm{C}$ [von Blanckenburg et al., 1989; Villa, 1998]. This implies that a white-mica-based Rb-Sr age from a mylonitic rock potentially reflects cooling only if crystallization of the mica took place above this temperature level, and if the crystal structure of the mica remained entirely unchanged at temperatures below $500-550^{\circ} \mathrm{C}$. However, ductile deformation at greenschist-facies conditions generally leads to dynamic recrystallization of white mica, which promotes $\mathrm{Sr}$ isotopic equilibration of mica with coevally 

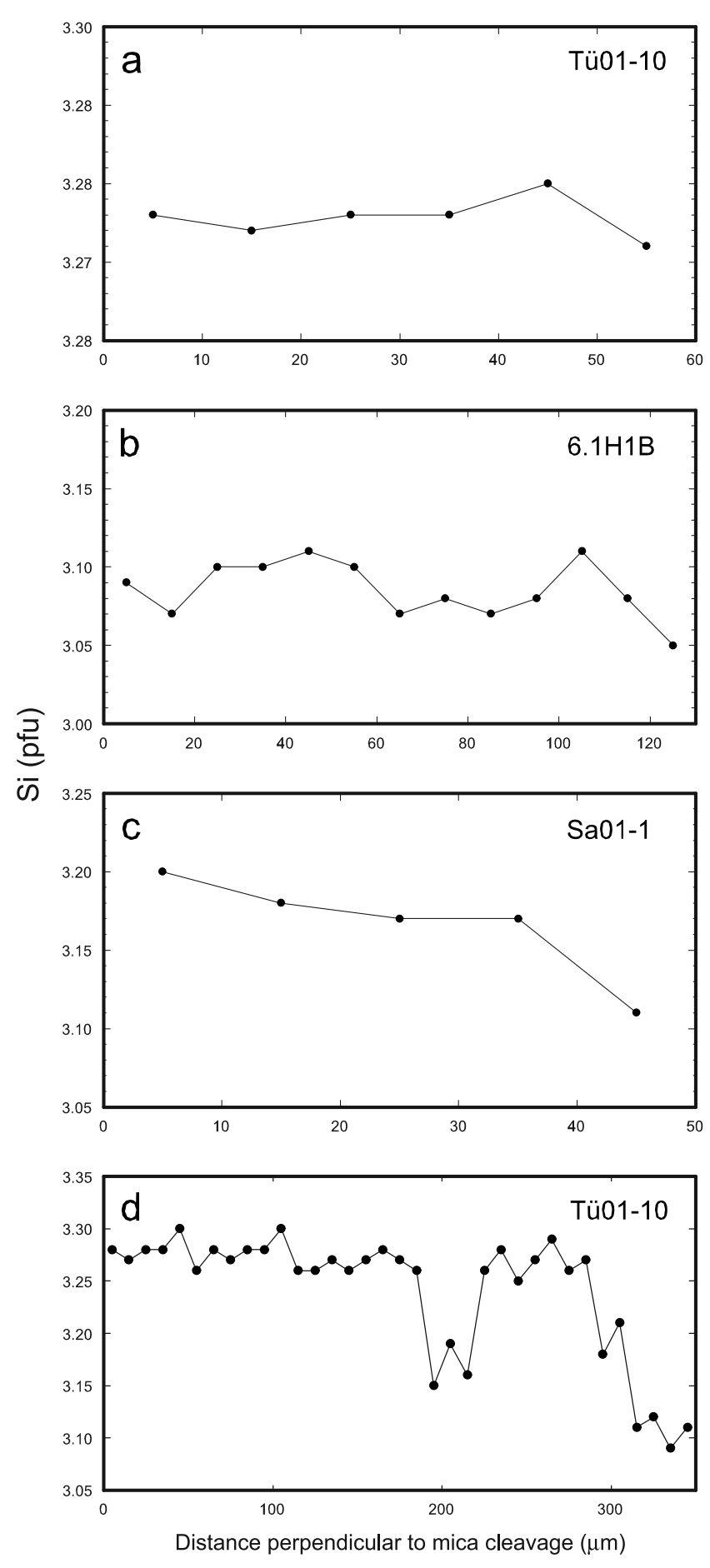

Figure 9. Composition profiles across single white mica grains from samples (a) Tü01-10, (b) 6.1H1B, and (c) Sa01-1. Profiles were taken perpendicular to mica cleavage and show largely homogeneous Si distribution (compare Figure 8). (d) Profile across several white mica grains from sample Tü01-10 showing scatter in $\mathrm{Si}$ values from one grain to another. Each grain is largely homogeneous. recrystallizing phases and thus permits direct dating of the end of ductile deformation by employing entirely reequilibrated domains of a rock (see detailed discussion by Freeman et al. [1997]). The recognition of deformationinduced $\mathrm{Sr}$ isotopic reequilibration forms the basis for numerous recent studies in shear zone geochronology. Depending on the size of dynamically recrystallized and isotopically equilibrated domains of a rock, the methods of choice for determining deformation ages are either $\mathrm{Rb}-\mathrm{Sr}$ microsampling [Müller et al., 2000, 2001; Cliff and MeffanMain, 2003] or mineral separation from carefully selected small ( $\mathrm{cm}^{3}$-sized) samples [Freeman et al., 1997; Reddy et al., 2003; Glodny et al., 2005a, 2005b; this study]. For the present study, late increments of deformation and related white mica recrystallization in our samples occurred at temperatures $<500-550^{\circ} \mathrm{C}$, which ensures that $\mathrm{Rb}-\mathrm{Sr}$ isotopic signatures record deformation.

[33] For the K-Ar system of white mica, there is ample evidence that thermally driven Ar diffusion is feasible only at temperatures well above the commonly quoted closure temperatures [Scaillet et al., 1992; Villa, 1998; Federico et $a l ., 2005]$. In the demonstrable absence of dynamic or fluidinduced recrystallization, muscovitic/phengitic white mica generally retains $\mathrm{Ar}$ isotopic signatures at temperatures below $500-550^{\circ} \mathrm{C}$, as shown and discussed conclusively by $D i$ Vincenzo et al. [2001, 2004]. It follows that at blueschist- and greenschist-facies conditions, deformation and associated recrystallization is much more efficient than temperature in resetting both the $\mathrm{K}-\mathrm{Ar}$ and the $\mathrm{Rb}-\mathrm{Sr}$ isotope systems of mica phases [Freeman et al., 1997; Dunlap, 1997; Villa, 1998; Müller et al., 1999; Kühn et al., 2000; Ring and Layer, 2003]. In the same way as the $\mathrm{Rb}-\mathrm{Sr}$ system, the K-Ar system of white mica has recently successfully been used to directly date greenschist-facies deformation [Reddy et al., 1997; Challandes et al., 2003; Di Vincenzo et al., 2001, 2004]. Since metamorphic temperatures in our study area were below the activation temperature for Ar diffusion in white mica, we conclude that our ${ }^{40} \mathrm{Ar}-{ }^{39} \mathrm{Ar}$ ages should either date metamorphic mica crystal growth or dynamic recrystallization.

\section{7. $\mathrm{Rb}-\mathrm{Sr}$ Ages}

[34] $\mathrm{Rb}$-Sr geochronology yields strikingly similar age information from the lower and upper contact of the Ampelos/Dilek nappe. Deformation ages have been calculated using $\mathrm{Rb}-\mathrm{Sr}$ data for apatite and small grain size $(<500 \mu \mathrm{m})$ white mica, as these phases readily recrystallize during deformation.

[35] Mylonitization ages from the Cyclades-Menderes thrust are identical within limits of error at $34.4 \pm 2.6 \mathrm{Ma}$ (sample Tü01-4) (all reported errors are quoted at the $2 \sigma$ level) and $32.5 \pm 0.4 \mathrm{Ma}$ (sample Tü01-9) (Table 2 and Figures 10a and 10b). Magnetic separation of the white mica populations at grain sizes $<500 \mu \mathrm{m}$ revealed a wide range of magnetic properties, possibly related to tiny ferromagnetic inclusions, but a homogeneous signature with respect to $\mathrm{Rb}, \mathrm{Sr}$ concentrations and age information. In contrast, the $\mathrm{Rb}-\mathrm{Sr}$ isotopic signature of the largest white mica crystals, in the sieve fraction $>500 \mu \mathrm{m}$, differs as the 
Table 2. $\mathrm{Rb} / \mathrm{Sr}$ Analytical Data ${ }^{\mathrm{a}}$

\begin{tabular}{|c|c|c|c|c|c|c|}
\hline Analysis & Material & $\begin{array}{l}\mathrm{Rb}, \\
\mathrm{ppm}\end{array}$ & $\begin{array}{l}\mathrm{Sr}, \\
\mathrm{ppm}\end{array}$ & ${ }^{87} \mathrm{Rb} /{ }^{86} \mathrm{Sr}$ & ${ }^{87} \mathrm{Sr} /{ }^{86} \mathrm{Sr}$ & $\begin{array}{c}{ }^{87} \mathrm{Sr} /{ }^{86} \mathrm{Sr} \\
2 \sigma_{\mathrm{m}} \\
\%\end{array}$ \\
\hline \multicolumn{7}{|c|}{ Sample Tü01-4b } \\
\hline PS910 & $\mathrm{wm} \mathrm{m}=0.8 \mathrm{~A}$ & 207 & 130 & 4.61 & 0.711742 & 0.0014 \\
\hline PS911 & $\mathrm{wm} \mathrm{m}=0.4 \mathrm{~A}$ & 205 & 131 & 4.54 & 0.711651 & 0.0016 \\
\hline PS912 & $\mathrm{wm} \mathrm{m}=2.2 \mathrm{~A}$ & 205 & 124 & 4.77 & 0.711789 & 0.0016 \\
\hline PS913 & $\mathrm{wm}>500 \mu \mathrm{m}$ & 216 & 120 & 5.21 & 0.712154 & 0.0012 \\
\hline PS962 & whole rock & 25.8 & 21.8 & 3.43 & 0.711026 & 0.0012 \\
\hline PS914 & apatite & 0.68 & 1119 & 0.00177 & 0.709446 & 0.0016 \\
\hline PS963 & $\mathrm{wm} \mathrm{m}=1.3 \mathrm{~A}$ & 207 & 127 & 4.71 & 0.711685 & 0.0014 \\
\hline \multicolumn{7}{|c|}{ Sample Tü01-9c } \\
\hline PS915 & $\mathrm{wm}>500 \mu \mathrm{m}$ & 224 & 52.5 & 12.3 & 0.722399 & 0.0014 \\
\hline PS916 & $\mathrm{wm} \mathrm{m}=1.27 \mathrm{~A}$ & 205 & 55.8 & 10.6 & 0.721302 & 0.0014 \\
\hline PS917 & $\mathrm{wm} \mathrm{m}=0.4 \mathrm{~A}$ & 221 & 58.6 & 10.9 & 0.721425 & 0.0012 \\
\hline PS919 & apatite & 0.94 & 1916 & 0.00142 & 0.716404 & 0.0012 \\
\hline PS964 & $\mathrm{wm} \mathrm{m}=0.87 \mathrm{~A}$ & 219 & 58.1 & 10.9 & 0.721487 & 0.0018 \\
\hline \multicolumn{7}{|c|}{ Sample SA01-1 ${ }^{\mathrm{d}}$} \\
\hline PS902 & $\begin{array}{r}\mathrm{wm} \mathrm{m}=0.8 \mathrm{~A} \\
180-160 \mu \mathrm{m}\end{array}$ & 230 & 143 & 4.65 & 0.722851 & 0.0020 \\
\hline PS903 & $\begin{array}{r}\mathrm{wm} \mathrm{m}=0.5 \mathrm{~A} \\
125-100 \mu \mathrm{m}\end{array}$ & 324 & 70.2 & 13.4 & 0.727183 & 0.0014 \\
\hline PS904 & $\begin{array}{r}\mathrm{wm} \mathrm{m}=0.5 \mathrm{~A} \\
125-160 \mu \mathrm{m}\end{array}$ & 339 & 77.2 & 12.7 & 0.726923 & 0.0012 \\
\hline PS960 & whole rock & 36.3 & 29.3 & 3.59 & 0.722015 & 0.0012 \\
\hline
\end{tabular}

${ }^{\mathrm{a}}$ Errors are reported at the $2 \sigma$ level. An uncertainty of $\pm 1.5 \%$ is assigned to $\mathrm{Rb} / \mathrm{Sr}$ ratios; wm, white mica; $\mathrm{m}$, magnetic on Frantz magnetic separator, $13^{\circ}$ tilt, at electric current as indicated.

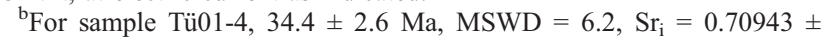
0.00015 ; excluding $\mathrm{wm}>500 \mu \mathrm{m}$.

${ }^{\mathrm{c}}$ For sample Tü01-9, $32.5 \pm 0.4 \mathrm{Ma}$, MSWD $=0.8, \mathrm{Sr}_{\mathrm{i}}=0.716403 \pm$ 0.000035 , excluding $\mathrm{wm}>500 \mu \mathrm{m}$.

${ }^{\mathrm{d}}$ For sample SA01-1, $37 \pm 5 \mathrm{Ma}, \mathrm{MSWD}=33, \mathrm{Sr}_{\mathrm{i}}=0.72029 \pm 0.00068$.

data plot above the isochrons defined by the fine-grained white mica fractions (Figures 10a and 10b). Corresponding apatite-white mica apparent ages formally are $36.6 \pm 0.9 \mathrm{Ma}$ (sample Tü01-4) and 34.2 $\pm 0.6 \mathrm{Ma}$ (sample Tü01-9). This pattern indicates a positive correlation between grain size and apparent white mica age, which may be explained either by diffusion processes during static cooling, or as a deformation-induced effect. Static cooling appears to be unlikely

Figure 10. $\mathrm{Rb}-\mathrm{Sr}$ isochron diagrams; all errors are $2 \sigma$. (a) Sample Tü01-4 showing effects of progressive recrystallization of white mica. Data point for white mica $>500 \mu \mathrm{m}$ plots above regression line for other phases and whole rock, indicating that age of $34.4 \pm 2.6$ Ma reflects late stages of mylonitzation. (b) Data for sample Tü01-9 show same pattern. Fine-grained white micas are distinguished by magnetic properties. (c) Sample Sa01-1 from Selçuk normal shear zone with white micas with distinctly different $\mathrm{Rb}, \mathrm{Sr}$ ratios. Less paramagnetic fraction $(\mathrm{m}=0.8 \mathrm{~A})$ is phengite/paragonite mixture. More strongly paramagnetic white mica $(\mathrm{m}=0.5 \mathrm{~A})$ is phengitic/muscovitic in composition and does not show age-grain size correlation; $37 \pm 5 \mathrm{Ma}$ dates late increments of shear. Compare to Table 2. a

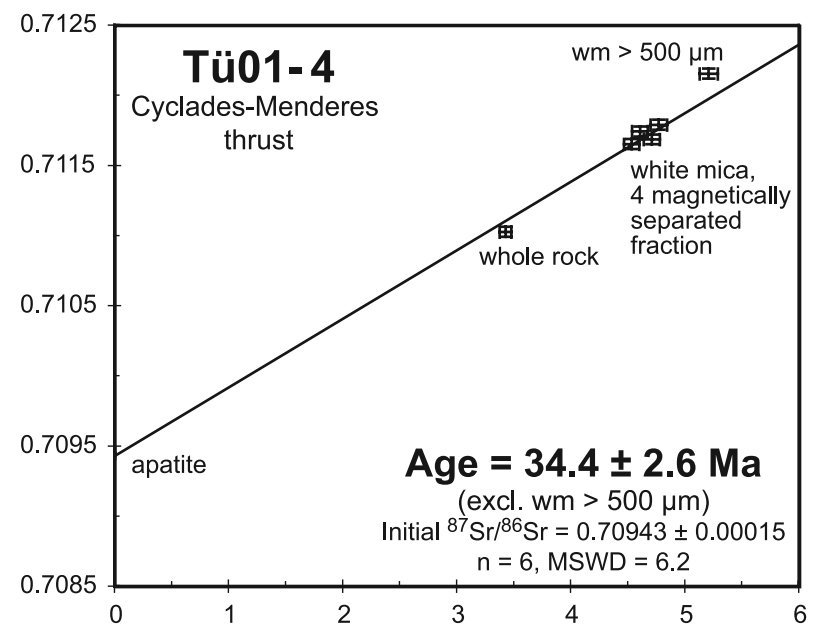

b

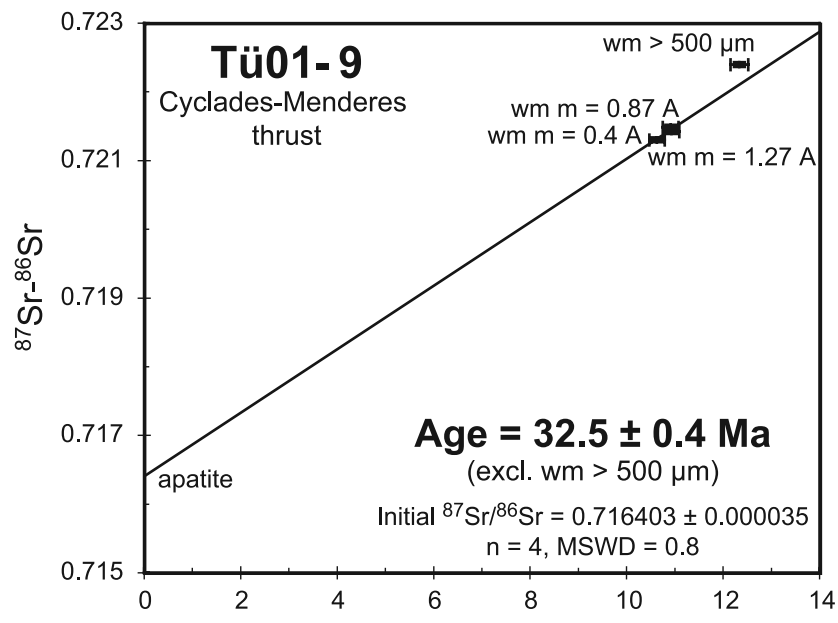

C

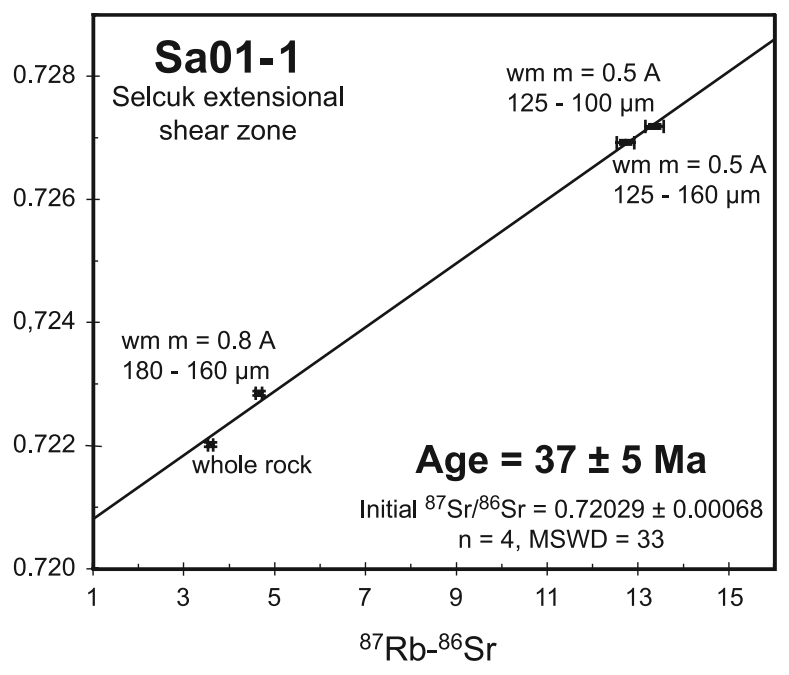


Table 3. The ${ }^{39} \mathrm{Ar} /{ }^{40} \mathrm{Ar}$ Data (Step Heating) ${ }^{\mathrm{a}}$

\begin{tabular}{|c|c|c|c|c|c|c|c|c|}
\hline Step & ${ }^{40} \mathrm{Ar} *{ }^{39} \mathrm{Ar}$ & $\begin{array}{c}{ }^{36} \mathrm{Ar} /{ }^{40} \mathrm{Ar} \times 1000 \\
\mathrm{~J}=0.013337\end{array}$ & ${ }^{39} \mathrm{Ar} /{ }^{40} \mathrm{Ar}$ & ${ }^{37} \mathrm{Ar} r^{39} \mathrm{Ar}$ & $\begin{array}{l}\text { Percent } \\
{ }^{39} \mathrm{Ar}\end{array}$ & $\begin{array}{l}\text { Percent } \\
\text { Atm }\end{array}$ & $\begin{array}{l}\text { Age, } \\
\text { Ma }\end{array}$ & $\begin{array}{c}\text { Error } \\
1 \sigma\end{array}$ \\
\hline \multicolumn{9}{|c|}{ Тü 01-9 } \\
\hline 1 & 0.241 & 3.203 & 0.2215 & 0.463 & 0.6 & 94.6 & 41.9 & 5.8 \\
\hline 2 & 1.835 & 0.458 & 0.4708 & 0.394 & 5.1 & 13.5 & 43.6 & 10.1 \\
\hline 3 & 1.415 & 0.535 & 0.5946 & 0.012 & 38.2 & 15.8 & 33.7 & 0.9 \\
\hline 4 & 1.404 & 0.549 & 0.5963 & 0.017 & 56.8 & 16.2 & 33.5 & 1.5 \\
\hline 5 & 1.608 & 0.174 & 0.5895 & 0.002 & 69.8 & 5.1 & 38.3 & 1.7 \\
\hline 6 & 1.512 & 0.106 & 0.6403 & 0.000 & 79.1 & 3.1 & 36.0 & 4.6 \\
\hline 7 & 1.402 & 0.171 & 0.6768 & 0.000 & 82.9 & 5.0 & 33.4 & 3.2 \\
\hline 8 & 1.284 & 0.253 & 0.7203 & 0.080 & 85.4 & 7.4 & 30.6 & 4.7 \\
\hline 9 & 1.485 & 2.394 & 0.1967 & 0.000 & 87.4 & 70.7 & 35.4 & 10.2 \\
\hline 10 & 1.242 & 0.411 & 0.7066 & 0.000 & 89.1 & 12.1 & 29.7 & 7.6 \\
\hline 11 & 1.512 & 0.214 & 0.6190 & 0.021 & 100.0 & 6.3 & 36.0 & 1.2 \\
\hline \multicolumn{9}{|c|}{ Tü $01-10^{\mathrm{c}}$} \\
\hline 1 & 1.778 & 2.725 & 0.1093 & 0.000 & 0.2 & 80.5 & 42.3 & 69.5 \\
\hline 2 & 1.461 & 0.327 & 0.6178 & 0.000 & 1.7 & 9.6 & 34.8 & 11.6 \\
\hline 3 & 1.626 & 0.297 & 0.5607 & 0.000 & 11.1 & 8.7 & 38.7 & 1.7 \\
\hline 4 & 1.393 & 0.396 & 0.6335 & 0.004 & 27.5 & 11.7 & 33.2 & 1.7 \\
\hline 5 & 1.337 & 0.512 & 0.6344 & 0.013 & 40.4 & 15.1 & 31.9 & 1.6 \\
\hline 6 & 1.464 & 0.072 & 0.6684 & 0.004 & 75.2 & 2.1 & 34.9 & 0.7 \\
\hline 7 & 1.509 & 0.030 & 0.6562 & 0.000 & 86.4 & 0.9 & 36.0 & 0.6 \\
\hline 8 & 1.493 & 0.068 & 0.6560 & 0.000 & 91.4 & 2.0 & 35.6 & 1.3 \\
\hline 9 & 1.431 & 0.203 & 0.6567 & 0.000 & 94.8 & 6.0 & 34.1 & 5.9 \\
\hline 10 & 1.350 & 0.212 & 0.6937 & 0.104 & 96.7 & 6.2 & 32.2 & 9.3 \\
\hline 11 & 1.374 & 0.251 & 0.6736 & 0.000 & 98.1 & 7.4 & 32.8 & 4.8 \\
\hline 12 & 1.264 & 0.320 & 0.7155 & 0.100 & 99.2 & 9.4 & 30.2 & 16.0 \\
\hline 13 & 1.515 & 0.420 & 0.5776 & 0.000 & 100.0 & 12.4 & 36.1 & 9.3 \\
\hline \multicolumn{9}{|c|}{ Tü 01-4 ${ }^{\mathrm{d}}$} \\
\hline 1 & 4.387 & 0.372 & 0.2028 & 0.000 & 0.3 & 11.0 & 102.6 & 22.6 \\
\hline 2 & 1.703 & 0.802 & 0.4477 & 0.000 & 9.8 & 23.7 & 40.5 & 2.8 \\
\hline 3 & 1.658 & 0.016 & 0.5999 & 0.000 & 35.6 & 0.5 & 39.5 & 0.4 \\
\hline 4 & 1.630 & 0.016 & 0.6104 & 0.000 & 62.7 & 0.4 & 38.8 & 0.4 \\
\hline 5 & 1.576 & 0.073 & 0.6206 & 0.004 & 75.0 & 2.1 & 37.5 & 2.2 \\
\hline 6 & 1.635 & 0.051 & 0.6021 & 0.000 & 83.5 & 1.5 & 38.9 & 1.1 \\
\hline 7 & 1.545 & 0.080 & 0.6316 & 0.000 & 89.2 & 2.3 & 36.8 & 1.7 \\
\hline 8 & 1.569 & 0.106 & 0.6171 & 0.000 & 93.4 & 3.1 & 37.4 & 2.2 \\
\hline 9 & 1.662 & 0.144 & 0.5757 & 0.000 & 99.2 & 4.2 & 39.6 & 3.5 \\
\hline 10 & 1.372 & 0.130 & 0.7005 & 0.000 & 110.0 & 3.8 & 32.7 & 26.2 \\
\hline
\end{tabular}

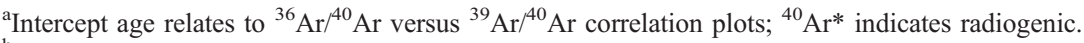

${ }^{\mathrm{b}}$ Total age $34.8 \pm 1.8$; intercept age $34.1 \pm 1.6(\mathrm{MSWD}=1.23)$.

${ }^{\mathrm{c}}$ Total age $34.6 \pm 1.4$, intercept age $34.9 \pm 1.6(\mathrm{MSWD}=1.01)$.

${ }^{\mathrm{d}}$ Total age $39.0 \pm 1.2 ;$ intercept age $38.9 \pm 1.0(\mathrm{MSWD}=0.57)$.

as deformation fabrics point to deformation temperatures below those necessary for activation of intracrystalline $\mathrm{Rb}-\mathrm{Sr}$ diffusion. Instead, it is well known that progressive deformation in mylonites at decreasing temperatures causes grain size reduction, leaving "large" white mica crystals (mica fish) as textural and isotopic relics from earlier stages of ductile deformation [Müller et al., 1999; Mulch and Cosca, 2004]. Therefore we interpret the contrasting apparent ages for different grain size fractions as reflecting a prolonged process of dynamic recrystallization. The apparent ages for the largest white micas are thus interpreted as minimum ages for crystallization of these white micas, either in a predeformational setting or at some stage of progressive deformation. As the white mica fractions $<500 \mu \mathrm{m}$ may contain both fragments of larger crystals, and particularly small crystals which recrystallized during the latest stages of ductile deformation, the apparent ages for the "small" grain size white mica fractions are "mixed ages," interpretable as maximum ages for the latest increments of ductile deformation.

[36] No apatite has been found in sample Sa01-1 from the upper contact of the Ampelos/Dilek nappe in the Selçuk normal shear zone. Further, we did not manage to produce a clean feldspar fraction. Magnetic separation of the white mica populations revealed two chemically distinct white micas. The less paramagnetic white mica (magnetic fraction at $0.8 \mathrm{~A} / 13^{\circ}$ Frantz magnetic separator, Table 2) has significantly less $\mathrm{Rb}$ and more $\mathrm{Sr}$, which relates to presence of some paragonite in this fraction. Rock texture suggests that some of these phengite/paragonite intergrowths form textural relics within an otherwise penetratively deformed matrix (Figure $5 \mathrm{c}$ ). For the more strongly paramagnetic, phengitic/muscovitic white mica fractions (magnetic at $0.5 \mathrm{~A} / 13^{\circ}$, Table 2), Rb-Sr data show that there is no agegrain size correlation (Figure 10c), which is in line with complete synkinematic recrystallization as inferred from 

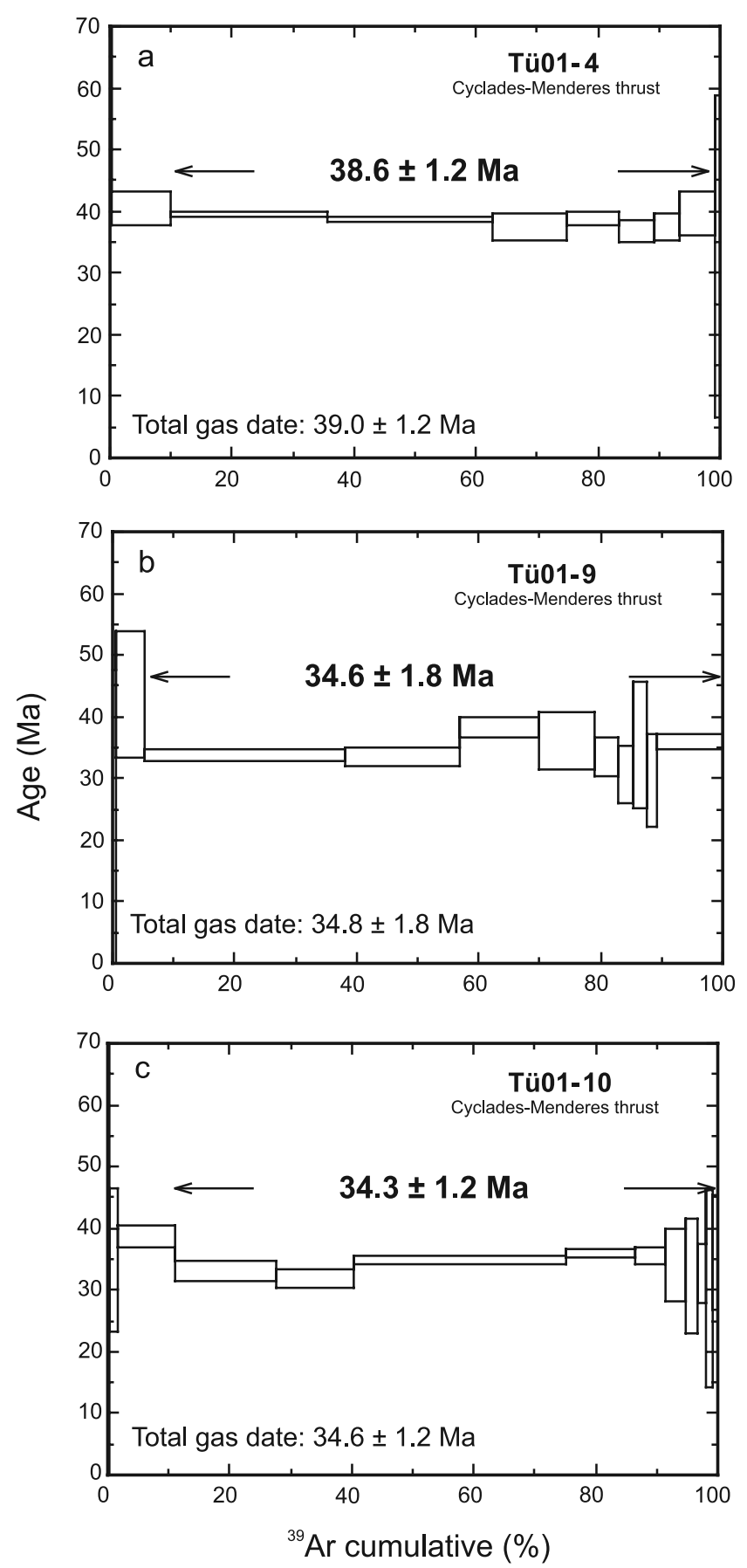

Figure 11. The ${ }^{40} \mathrm{Ar}-{ }^{39} \mathrm{Ar}$ step-heating results from Cyclades-Menderes thrust. Errors are quoted to $2 \sigma$ level. (a) The ${ }^{40} \mathrm{Ar}-{ }^{39} \mathrm{Ar}$ apparent age spectrum for sample Tü01-4 yielding well-defined age for $95 \%$ of released ${ }^{39} \mathrm{Ar}$. (b) Apparent age spectrum for sample Tü01-9. Age is defined by $88 \%$ of released ${ }^{39}$ Ar. (c) Age spectrum for sample Tü01-10 showing similar degassing behavior as other samples and well-defined plateau ages for $89 \%$ of released ${ }^{39}$ Ar. Compare to Table 3. textural observations. Despite evidence for incipient weathering, the whole rock was analyzed as well. Integration of the whole rock data with the different white mica results leads to an apparent deformation age of $37 \pm 5 \mathrm{Ma}$. Given the large spread in $\mathrm{Rb}-\mathrm{Sr}$ ratios between the different analytical data, the error on this age value accounts for age uncertainties introduced by the rare textural mica relics and by possible weathering effects on the whole rock system. We therefore interpret $37 \pm 5 \mathrm{Ma}$ as an accurate estimate for late stages of mylonitic deformation.

\subsection{The ${ }^{40} \mathrm{Ar} /{ }^{39} \mathrm{Ar}$ Ages}

[37] Step-heating results from the Cyclades-Menderes thrust yielded well-defined plateaus ranging in age from $34.3 \pm 1.2 \mathrm{Ma}$ to $38.6 \pm 1.2 \mathrm{Ma}$ (Table 3 and Figure 11). Isochron calculations with similar age results suggest that the Ar is not contaminated by an excess component. The first heating steps for each sample show a large amount of atmospheric Ar probably released from the surface of structural defects of the mineral at the beginning of degassing.

[38] Weighted mean laser spot fusion ${ }^{40} \mathrm{Ar}-{ }^{39} \mathrm{Ar}$ ages for the samples from the Cyclades-Menderes thrust are similar to the step-heating results and yielded mean ages ranging from 33.6 $\pm 3.6 \mathrm{Ma}$ to $36.4 \pm 6.2 \mathrm{Ma}$ (Table 4 and Figure 12). Weighted mean spot fusion ages for the Selçuk normal shear zone range from $35.3 \pm 4.0 \mathrm{Ma}$ to $41.5 \pm$ 4.0 Ma (Table 4).

[39] A relatively large variation in ages of $\sim 10 \mathrm{Ma}$ is visible in all six samples analyzed by the spot fusion technique (Table 4 and Figure 12). Two premylonitic, nonrecrystallized, high-Si phengite/paragonite intergrowths in sample Sa01-1 (Figure 5c) yielded ages of $\sim 50 \mathrm{Ma}$. In all other five samples no premylonitic grains were detected and these samples yielded no spot fusion ages $<\sim 42 \mathrm{Ma}$. Analyzed spots from relatively coarse-grained $(\sim 60-80 \mu \mathrm{m})$, early recrystallized phengites in mylonitically sheared layers (Figures 5c and 5d) give systematically older ages than spots from late stage recrystallized phengites $(<\sim 50 \mu \mathrm{m})$. In line with our interpretation of the $\mathrm{Rb}-\mathrm{Sr}$ ages, we interpret the scatter of the ${ }^{40} \mathrm{Ar}^{39} \mathrm{Ar}$ spot fusion ages to be due to progressive recrystallization of phengite. Accordingly we propose that the scatter in ages reflects different increments of shear zone deformation.

\subsection{Apatite Fission Track Ages}

[40] We obtained apatite fission track ages ranging from $34.8 \pm 4.5 \mathrm{Ma}$ for sample Tü01-4, 28.2 $\pm 12.2 \mathrm{Ma}$ for sample Tü01-5 and 27.4 \pm 4.8 Ma for sample Tü01-9 (Table 5). The ages indicate that the Dilek/Ampelos nappe reached high crustal levels in the Oligocene.

\section{Structures}

[41] A detailed structural study by Gessner et al. [2001a] showed that the Ampelos/Dilek nappe was emplaced onto the underlying Menderes nappes along the large-scale outof-sequence Cyclades-Menderes thrust (Figures 3 and 4). The Cyclades-Menderes thrust is a ductile shear zone with a 
Table 4. The ${ }^{40} \mathrm{Ar}^{39} \mathrm{Ar}$ Analytical Data (Spot Fusion)

\begin{tabular}{|c|c|c|c|c|c|c|c|}
\hline Mineral & ${ }^{40} \mathrm{Ar} *{ }^{39} \mathrm{Ar}$ & ${ }^{36} \mathrm{Ar} /{ }^{40} \mathrm{Ar} \times 1000 \mathrm{~J}=0.013337$ & ${ }^{39} \mathrm{Ar} /{ }^{40} \mathrm{Ar}$ & ${ }^{37} \mathrm{Ar} /{ }^{39} \mathrm{Ar}$ & $\%$ Atm & Age, Ma & Error $1 \sigma$ \\
\hline & & & $6.1 H 1 B$ & & & & \\
\hline 1 & 1.487 & 0.014 & 0.6695 & 0.000 & 0.4 & 35.4 & 1.2 \\
\hline 2 & 1.501 & 0.034 & 0.6592 & 0.000 & 1.0 & 35.8 & 2.4 \\
\hline 3 & 1.752 & 0.389 & 0.5049 & 0.000 & 11.5 & 41.7 & 1.2 \\
\hline 4 & 1.434 & 0.244 & 0.6470 & 0.002 & 7.2 & 34.2 & 2.4 \\
\hline 5 & 1.414 & 0.038 & 0.6990 & 0.000 & 1.1 & 33.7 & 1.1 \\
\hline 6 & 1.313 & 0.468 & 0.6558 & 0.024 & 13.8 & 31.3 & 3.0 \\
\hline \multirow[t]{2}{*}{ Mean } & & & & & & 35.3 & 2.0 \\
\hline & & & $\mathrm{Sa} 01-1$ & & & & \\
\hline 1 & 2.223 & 0.272 & 0.4135 & 0.000 & 8.0 & 52.7 & 1.9 \\
\hline 2 & 1.857 & 0.600 & 0.4427 & 0.000 & 17.7 & 44.2 & 1.5 \\
\hline 3 & 1.550 & 0.584 & 0.5335 & 0.000 & 17.2 & 36.9 & 4.8 \\
\hline 4 & 1.774 & 0.312 & 0.5115 & 0.000 & 9.2 & 42.2 & 1.2 \\
\hline 5 & 1.800 & 0.181 & 0.5255 & 0.009 & 5.3 & 42.8 & 6.6 \\
\hline 6 & 2.143 & 0.258 & 0.4308 & 0.000 & 7.6 & 50.9 & 2.0 \\
\hline \multirow[t]{2}{*}{ Mean } & & & & & & 41.5 & 2.0 \\
\hline & & & Тӥ 01-9 & & & & \\
\hline 1 & 1.194 & 0.682 & 0.6682 & 0.017 & 20.1 & 28.5 & 2.9 \\
\hline 2 & 1.443 & 0.154 & 0.6608 & 0.000 & 4.5 & 34.4 & 0.9 \\
\hline 3 & 1.625 & 0.057 & 0.6046 & 0.000 & 1.6 & 38.7 & 1.3 \\
\hline 4 & 1.543 & 0.060 & 0.6364 & 0.000 & 1.7 & 36.8 & 1.3 \\
\hline 5 & 1.450 & 0.132 & 0.6625 & 0.028 & 3.9 & 34.6 & 2.7 \\
\hline 6 & 1.423 & 0.102 & 0.6814 & 0.000 & 3.0 & 33.9 & 2.0 \\
\hline 7 & 1.445 & 0.082 & 0.6746 & 0.009 & 2.4 & 34.5 & 1.4 \\
\hline \multirow[t]{2}{*}{ Mean } & & & & & & 35.5 & 0.7 \\
\hline & & & Тӥ 01-10 & & & & \\
\hline 1 & 1.716 & 0.040 & 0.5756 & 0.000 & 1.2 & 40.8 & 2.2 \\
\hline 2 & 1.493 & 0.028 & 0.6641 & 0.023 & 0.8 & 35.6 & 1.7 \\
\hline 3 & 1.400 & 0.027 & 0.7081 & 0.007 & 0.8 & 33.4 & 1.4 \\
\hline 4 & 1.359 & 0.009 & 0.7337 & 0.000 & 0.2 & 32.4 & 0.7 \\
\hline 5 & 1.671 & 0.013 & 0.5960 & 0.000 & 0.4 & 39.8 & 1.1 \\
\hline 6 & 1.449 & 0.286 & 0.6316 & 0.024 & 8.4 & 34.5 & 6.3 \\
\hline 7 & 1.295 & 0.037 & 0.7634 & 0.000 & 1.0 & 30.9 & 1.7 \\
\hline 8 & 1.449 & 0.027 & 0.6840 & 0.004 & 0.8 & 34.5 & 1.8 \\
\hline \multirow[t]{2}{*}{ Mean } & & & & & & 35.2 & 0.7 \\
\hline & & & Тӥ 01-8 & & & & \\
\hline 1 & 1.310 & 1.280 & 0.4745 & 0.058 & 37.8 & 31.3 & 1.2 \\
\hline 2 & 1.429 & 0.732 & 0.5480 & 0.074 & 21.6 & 34.1 & 3.0 \\
\hline 3 & 1.341 & 0.984 & 0.5286 & 0.052 & 29.0 & 32.0 & 1.2 \\
\hline 4 & 1.351 & 0.977 & 0.5263 & 0.120 & 28.8 & 32.2 & 1.5 \\
\hline 5 & 1.628 & 0.906 & 0.4494 & 0.074 & 26.7 & 38.8 & 2.3 \\
\hline 6 & 1.551 & 1.033 & 0.4477 & 0.279 & 30.5 & 37.0 & 1.1 \\
\hline 7 & 1.250 & 1.210 & 0.5134 & 0.049 & 35.7 & 29.8 & 1.8 \\
\hline \multirow[t]{2}{*}{ Mean } & & & & & & 33.6 & 1.8 \\
\hline & & & Tü 01-4 & & & & \\
\hline 1 & 1.770 & 0.342 & 0.50760 & 0.021 & 10.1 & 42.1 & 1.5 \\
\hline 2 & 1.473 & 0.178 & 0.64270 & 0.061 & 5.2 & 35.1 & 1.9 \\
\hline 3 & 1.296 & 0.680 & 0.61640 & 0.019 & 20.0 & 30.9 & 0.8 \\
\hline 4 & 1.391 & 0.290 & 0.65690 & 0.035 & 8.5 & 33.2 & 1.9 \\
\hline 5 & 1.602 & 0.625 & 0.50830 & 0.000 & 18.4 & 38.2 & 5.5 \\
\hline 6 & 1.400 & 0.590 & 0.58940 & 0.000 & 17.4 & 33.4 & 2.2 \\
\hline 7 & 1.751 & 0.200 & 0.53700 & 0.000 & 5.9 & 41.7 & 4.7 \\
\hline Mean & & & & & & 36.4 & 3.1 \\
\hline
\end{tabular}

thrust geometry and a top-to-the-S/SE sense of shear. Deformation/metamorphism relationships indicate that major tectonic movement occurred under greenschist-facies conditions. Especially the structures directly at the contact between the Cycladic blueschist unit and the Menderes nappes southwest of Tire (Figure 3) were extensively retrogressed and are lower greenschist-facies chlorite-white mica-quartz mylonites (Figure 6a). Garnet in metapelites from the uppermost Bozdag nappe is progressively retrograded and biotite and chlorite grew in asymmetric strain shadows. Close to the Cyclades-Menderes thrust, biotite is fully transformed into chlorite. Structural work by Ring et al. [1999b] at the base of the Ampelos/Dilek nappe on Samos Island showed that these early thrust-related struc- 
tures started to develop when glaucophane, epidote, chloritoid, kyanite and high-Si phengite were stable under blueschist-facies conditions. Rotated chloritoid porphyroclasts and shear bands locally indicate top-to-the-SE shear.

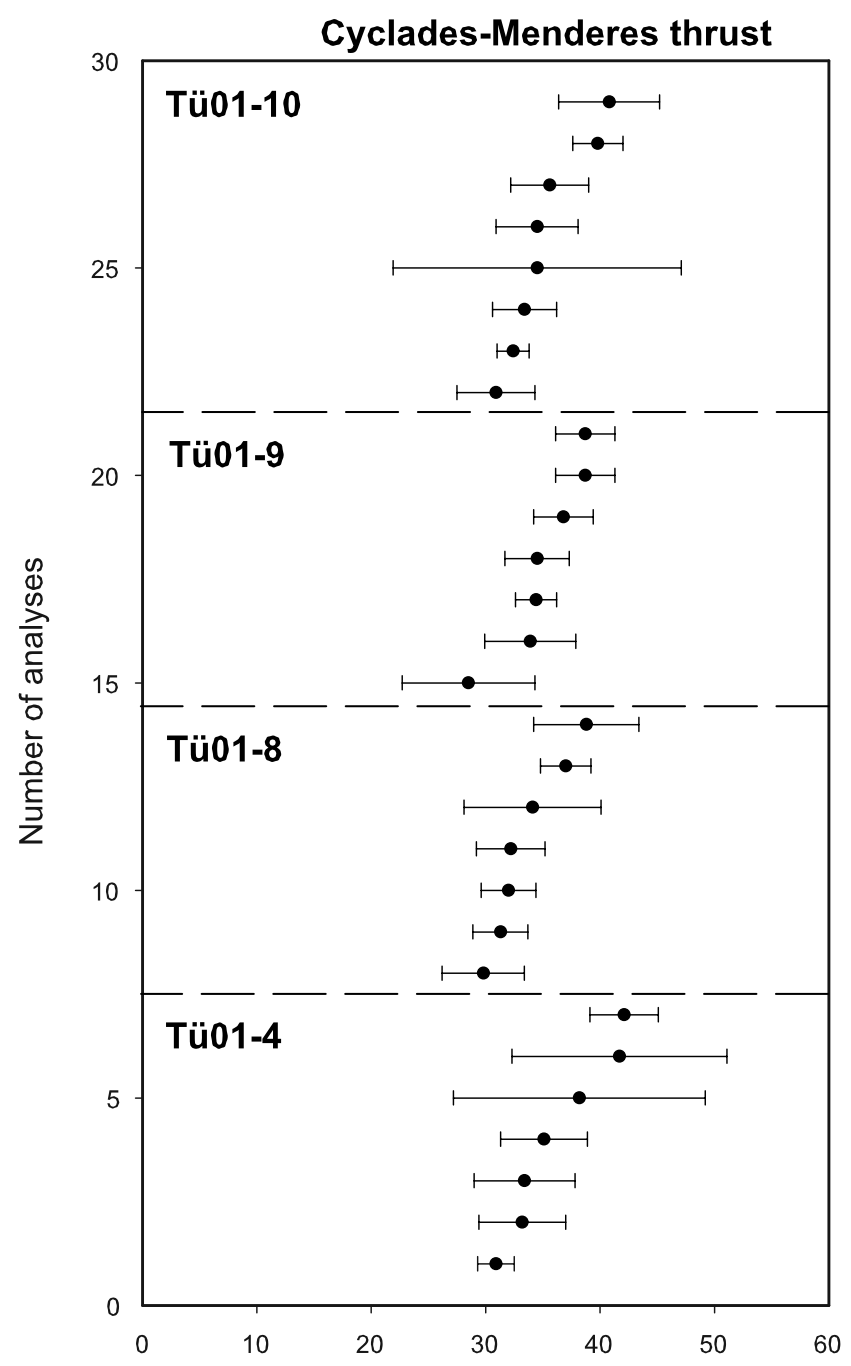

Selcuk extensional shear zone

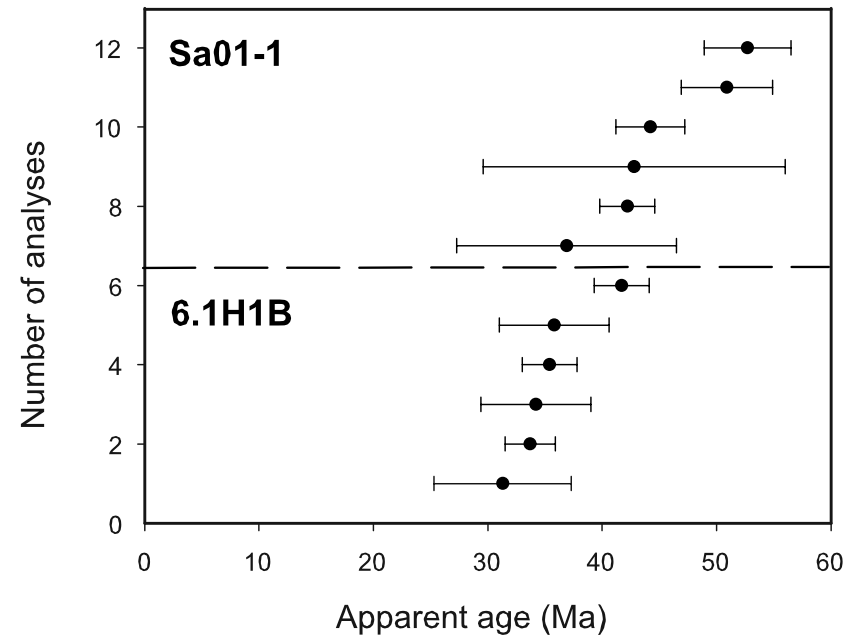

[42] Ring et al. [1999b] and Gessner et al. [2001a] mapped another mylonite zone between the Ampelos/Dilek nappe and the Selçuk nappe, which we name the Selçuk normal shear zone. The Selçuk normal shear zone is subparallel to the underlying Cyclades-Menderes thrust but the mylonitic structures show a top-to-the-NE/E shear sense, which is opposite to the one observed along the Cyclades-Menderes thrust. Deformation/metamorphism relationships in western Turkey indicate that the mylonitic top-to-the-NE/E shearing structures in the Ampelos/Dilek nappe directly below the Selçuk normal shear zone developed when kyanite, chloritoid, chlorite and high-Si phengite were stable (Figure 6b; see also Figure 7 of Gessner et al. [2001a]) under blueschist- and transitional blueschist/ greenschist-facies conditions during and after the growth of the peak pressure mineral assemblage [Will et al., 1998; Ring and Layer, 2003]. In the Ampelos Massif of Samos, mylonitic fabrics in the Selçuk nappe developed during retrogression of high-pressure assemblages. Metagabbro mylonites at the base of the Selçuk nappe contain porphyroclasts of Na pyroxene, brown hornblende, plagioclase and epidote, which occur in a very fine grained matrix of albite, epidote and chlorite. Mylonitic deformation has a top-tothe-E/NE sense of shear and commenced in the stability field of $\mathrm{Na}$ pyroxene and progressed during strongly retrogressive greenschist-facies shearing at the base of the Selçuk nappe. We mapped structures characterized by chloritoid, kyanite and phengite systematically from the top to the base of the Ampelos/Dilek nappe and find that toward the base of the nappe the sense of shear changes from top-to-the-NE/E to top-to-the-S/SE (Figures $6 \mathrm{~b}-6 \mathrm{~d}$ ). Furthermore, Gessner et al. [2001a] documented that the microstructural fabric data suggest a pronounced component of shortening across the foliation in addition to shearing parallel to it.

[43] The top-to-the-S/SE chloritoid-kyanite-phengitebearing porphyroclast systems at the base of the Ampelos/ Dilek nappe are in line with other deformation/metamorphism relationships indicating that the structures at the base of the nappe started to develop under blueschist-facies conditions and show a progressive evolution during decompression and exhumation. Furthermore, the structural evolution at the base of the Selçuk nappe on Samos shows that greenschist-facies mylonites developed during retrogression of high-pressure assemblages. Overall, the structural evolution is compatible with pervasive deformation in both shear zones under high-pressure conditions. Finally, the structures in both shear zones continued to develop during greenschist-facies conditions and became localized into relatively

\footnotetext{
Figure 12. The ${ }^{40} \mathrm{Ar}-{ }^{39} \mathrm{Ar}$ spot fusion results; bars represent $2 \sigma$ error from each individual analysis. Note relatively large spread in individual spot fusion ages of 9-16 Ma. Largest spread is seen in sample Sa01-1 where ages $>50 \mathrm{Ma}$ are from nonrecrystallized phengite. Compare to Table 4.
} 
Table 5. Apatite Fission Track Data From Footwall of Cyclades-Menderes Thrust

\begin{tabular}{|c|c|c|c|c|c|c|c|c|}
\hline \multirow[b]{2}{*}{ Sample } & \multirow{2}{*}{$\begin{array}{c}\text { Elevation, } \\
\mathrm{m}\end{array}$} & \multirow[b]{2}{*}{ Rock Type (Unit/Nappe) } & \multirow{2}{*}{$\begin{array}{l}\text { Number of } \\
\text { Crystals }\end{array}$} & \multicolumn{3}{|c|}{ Track Density, $\times 10^{6}$ tracks $\mathrm{cm}^{-2}$} & \multirow[b]{2}{*}{ Age Dispersion $\left(\mathrm{P} \chi^{2}\right)$} & \multirow{2}{*}{$\begin{array}{c}\text { Central Age } \pm 1 \sigma \\
\text { Ma }\end{array}$} \\
\hline & & & & $\rho_{\mathrm{s}}\left(\mathrm{N}_{\mathrm{s}}\right)$ & $\rho_{\mathrm{i}}\left(\mathrm{N}_{\mathrm{i}}\right)$ & $\rho_{\mathrm{d}}\left(\mathrm{N}_{\mathrm{d}}\right)$ & & \\
\hline Tü01-4 & 990 & mylonite (Dilek nappe) & 10 & $0.2265(68)$ & $1.632(490)$ & $1.466(4576)$ & $0.08 \%(84 \%)$ & $34.8 \pm 4.5$ \\
\hline Tü01-5 & 980 & mylonite (Dilek nappe) & 11 & $0.0146(6)$ & $0.1287(53)$ & 1.457 (4547) & $2.54 \%(64 \%)$ & $28.2 \pm 12.2$ \\
\hline Tü01-9 & 990 & mylonite (Dilek nappe) & 20 & $0.0502(41)$ & $0.4545(371)$ & $1.448(4518)$ & $24.8 \%(22 \%)$ & $27.4 \pm 4.8$ \\
\hline
\end{tabular}

narrow zones in the Cyclades-Menderes thrust and the Selçuk normal shear zone.

\section{Thrusting and Normal Faulting}

[44] Along the Cyclades-Menderes thrust the highpressure Ampelos/Dilek nappe was emplaced onto the distinctly lower-grade greenschist-facies Menderes nappes by top-to-the-S/SE thrust-type shearing. It is therefore plausible that the thrust was originally shallowly north dipping. The fact that the thrust-related structures show a progressive evolution from high-pressure to lower greenschist-facies conditions is compatible with the emplacement of the high-pressure Ampelos/Dilek nappe onto the greenschist-facies Menderes nappes.

[45] The relationships between deformation and chloritoid, kyanite and phengite growth indicate that the shear sense reversal from the base to the top of the Ameplos/Dilek nappe occurred during the same tectonometamorphic event. In the upper parts of the Ampelos/Dilek nappe, the topto-the-NE/E structures developed in the stability field of the chloritoid-kyanite assemblages with sample Sa90-111 recording the highest $\mathrm{PT}$ conditions. In metagabbros from the lowermost Selçuk nappe the high-pressure assemblages were strongly retrograded to greenschist-facies assemblages.

[46] Because the base of the Cycladic blueschist unit was a thrust, the reversed sense of shear at the upper contact of the Ampelos/Dilek nappe would constitute normal-sense shearing since the upper contact is subparallel to the basal contact of the Ampelos/Dilek nappe. A later reorientation of the Selçuk normal shear zone can be ruled out because such a reorientation would have been caused by prominent largescale folding or faulting of and near the shear zone. Such structures do not occur. Hence the Ampelos/Dilek nappe represents an extrusion wedge bounded by a thrust-type shear zone at its base and a normal-sense shear zone at its top. The consistent overprinting of high-pressure structures by greenschist-facies ones reflects progressive deformation as the extrusion wedge is being finally emplaced onto the Menderes nappes. The deformation/metamorphism relationships suggest that the Cyclades-Menderes thrust and the Selçuk normal shear zone evolved largely contemporaneously during high-pressure metamorphism and subsequent pronounced decompression. It is important to note that not only the Ampelos/Dilek nappe between the shear zones was exhuming but also the bounding shear zones as indicated by progressive change of metamorphic conditions in the mylonitic rocks.

\section{Discussion}

\subsection{Interpretation of Pressure-Temperature Data}

[47] Weakly deformed metagabbroic rocks from the Selçuk nappe yielded pressures of $11-13 \mathrm{kbar}$, at assumed temperatures of $450-500^{\circ} \mathrm{C}$. These PT conditions conform well to estimates of $12.4 \pm 1.2 \mathrm{kbar}$ and $550 \pm 18^{\circ} \mathrm{C}$ from sample Tü01-7. In contrast, strongly foliated mylonitized Selçuk nappe metagabbros at or close to the contact with the Selçuk normal shear zone consistently yielded PT values of $4 \pm 1.5 \mathrm{kbar}$ and $450 \pm 40^{\circ} \mathrm{C}$. This is in agreement with PT estimates of $3-$ $5 \mathrm{kbar}$ and $420-440^{\circ} \mathrm{C}$ obtained on omphacite-free mineral assemblages in the massive metagabbros, that occur either in the Selçuk normal shear zone or as small, isolated outcrops in the uppermost Ampelos/Dilek nappe.

[48] Evidence for high-pressure metamorphism in the Selçuk nappe is only preserved in the unfoliated samples, but is no longer present in the mylonitized metagabbros from the Selçuk normal shear zone. We think that this is due to fluid infiltration into the shear zone that produced the greenschist-facies, hydrated mineral assemblages in the metagabbros. In other words, the Eocene high-pressure metamorphism (11-13 kbar) of the Selçuk nappe was followed by a shearing-related greenschist-facies overprint at 3-5 kbar and these data imply that the Selçuk nappe must have been exhumed by at least $30 \mathrm{~km}$ between the highpressure metamorphism and the end of the mylonitization event. This decompression was accompanied by moderate cooling from $\sim 500^{\circ} \mathrm{C}$ to $420-440^{\circ} \mathrm{C}$.

[49] PT calculations on the strongly foliated chloritoidkyanite-white mica schists from the Ampelos/Dilek nappe gave rather consistent temperatures of $\sim 500-540^{\circ} \mathrm{C}$ and pressures ranging from $\sim 5-15$ kbar. Consequently, these rocks contain evidence of near isothermal decompression from eclogite- to epidote-amphibolite- and greenschistfacies conditions. Interestingly, the sample with the lowest inferred pressure (Tü01-3) occurs in the structural lowermost position of the nappe and records conditions that are very similar to those of the underlying Menderes nappes.

\subsection{Interpretation of Age Data}

[50] In our opinion, the $\mathrm{Rb}-\mathrm{Sr}$ and ${ }^{40} \mathrm{Ar}-{ }^{39} \mathrm{Ar}$ step-heating results average over the recrystallization ages of different 
white mica crystals and crystal domains, whereas the ${ }^{40} \mathrm{Ar}-{ }^{39} \mathrm{Ar}$ spot fusion ages directly reflect local ${ }^{40} \mathrm{Ar}-{ }^{39} \mathrm{Ar}$ age variations resulting from the protracted phengite growth and recrystallization history. All but two ${ }^{40} \mathrm{Ar}-{ }^{39} \mathrm{Ar}$ spot fusion ages have been set during progressive deformation and indicate prolonged deformation associated with white mica recrystallization and fluid flow. The two ages of $\sim 50 \mathrm{Ma}$ in sample Sa01-1 from nonrecrystallized high-Si phengite (Figure 5c) probably reflect mineral growth during highpressure metamorphism, prior to mylonitization. An alternative interpretation would be that weakly deformed, nonrecrystallized white mica retained excess Ar from the high-pressure growth stage. Because of mylonitization and strong, probably multiple recrystallization and associated fluid flow such an excess Ar component would not be present in the mylonitically sheared white mica anymore.

[51] From the Cyclades-Menderes thrust we obtained a number of consistent $\mathrm{Rb}-\mathrm{Sr}$ mineral and ${ }^{40} \mathrm{Ar}-{ }^{39} \mathrm{Ar}$ stepheating ages between $38.6 \pm 0.6 \mathrm{Ma}$ and $32.4 \pm 0.4 \mathrm{Ma}$. The ${ }^{40} \mathrm{Ar}^{39} \mathrm{Ar}$ spot fusion ages are as old as $42.1 \mathrm{Ma}$. In general, the $\mathrm{Rb}-\mathrm{Sr}$ ages are interpreted as maximum ages for the latest increments of ductile deformation. The deformation/ metamorphism relationships show that this stage corresponds to pronounced lower greenschist-facies mylonitization. Furthermore, the positive correlation between grain size and apparent white mica $\mathrm{Rb}-\mathrm{Sr}$ ages most probably reflects a prolonged process of partial dynamic recrystallization. The ${ }^{40} \mathrm{Ar}^{39} \mathrm{Ar}$ step-heating and spot fusion ages are basically similar to the $\mathrm{Rb}-\mathrm{Sr}$ ages and are thus interpreted in the same way. Because the deformation/metamorphism relationships indicate a gradual transition from high-pressure deformation to lower greenschist-facies retrogressive mylonitization at the Cyclades-Menderes thrust, we propose that this thrust operated between 42 and $32 \mathrm{Ma}$.

[52] Ring and Layer [2003] reported single-grain phengite ${ }^{40} \mathrm{Ar}-{ }^{39} \mathrm{Ar}$ step-heating ages from mylonitically deformed samples from the base of the Ampelos/Dilek nappe and the directly underlying Agios Nikolaos nappe on Samos (Figures 4 and 13) of $\sim 42-37 \mathrm{Ma}$ and interpreted these ages to date mylonitization during high-pressure metamorphism and associated phengite recrystallization.

[53] The $\mathrm{Rb}-\mathrm{Sr}$ and weighted mean ${ }^{40} \mathrm{Ar}-{ }^{39} \mathrm{Ar}$ spot fusion ages for white mica recrystallization from the Selçuk normal shear zone span a range between $41.5 \pm 4.0 \mathrm{Ma}$ and $35.3 \pm$ 4.0 Ma. The ${ }^{40} \mathrm{Ar}^{-39} \mathrm{Ar}$ spot fusion ages are as young as 31.3 Ma. Deformation/metamorphism relationships indicate that the ages relate to deformation during exhumation. The $\mathrm{Rb}-\mathrm{Sr}$ ages are again interpreted as maximum ages for the latest increments of normal-sense ductile shearing. The
${ }^{40} \mathrm{Ar}-{ }^{39} \mathrm{Ar}$ spot fusion ages of $\sim 42 \mathrm{Ma}$ obtained from early recrystallized high-Si phengite reflect older mylonitization increments. We interpret the age range of $\sim 42-31$ Ma to reflect the time span of progressive shearing in the Selçuk normal shear zone, coevally with mylonitization in the Cyclades-Menderes thrust zone.

[54] There are no indications for episodic motion in the studied shear zones that we can resolve with our age data. We envisage that slightly different ages in our samples reflect heterogeneous deformation within the shear zones. Mylonitization in an early segment of a large shear zone might have ceased while shearing shifted to other segments (along and across strike) of the same shear zone. A transfer of shearing between different segments of a shear zone might explain the spread in ages of $\sim 10 \mathrm{Ma}$ that we envisage as the life time of both studied shear zones. Our interpretation highlights the importance of deformation and associated fluid flow for setting the radiometric clock. The variation in radiogenic Ar is controlled by the heterogeneous distribution of grain boundary fluids and the apparent Ar spot fusion ages would reflect the time of loss of fluid in a segment of a sample over the time of mylonitization.

[55] The pressure estimates obtained from chloritoidkyanite schists of the upper Ampelos/Dilek nappe range from $\sim 5-15 \mathrm{kbar}$ at a relatively constant temperature of $\sim 500^{\circ} \mathrm{C}$. Over this pressure range the kinematics of the asymmetric structures around the chloritoid and kyanite porphyroclasts did not change (Figure 5d). We interpret the relationship between decompression, consistent kinematics of mylonitic shearing and a continuum in ages over a span of $\sim 10 \mathrm{Ma}$ to reflect a continuous deformation/ exhumation event. The PT estimates from mylonitic metagabbros from the base of the Selçuk nappe of 3-5 kbar/ $420-440^{\circ} \mathrm{C}$ and the kinematic indicators are similar to the ones from the chloritoid-kyanite schists and confirm that normal shearing took place during considerable decompression.

\subsection{Evidence for an Extrusion Wedge}

[56] By providing critical geochronologic evidence of mylonitization we show that the Selçuk normal shear zone and the Cyclades-Menderes thrust operated simultaneously in the late Eocene, which strongly suggests that thrust-type and normal-sense structures can operate at the same time in orogens. It should be noticed that during the late Eocene the entire region was undergoing overall convergence and shortening and that the normal-sense shearing is a geometric effect only and not an effect of net extension of the region.

[57] The deformation/metamorphism relationships indicate the Cyclades-Menderes thrust started to move during

Figure 13. (a) Proposed cross-sectional structure of late Eocene extrusion wedge with two normal-sense shear zones above basal thrust. According to age data it is apparent that Menderes nappes attained their peak metamorphism as Ampelos/Dilek nappe was emplaced onto them at 43-37 Ma. At about same time, contacts at the base of the Lycian nappe and Selçuk nappe were reactivated as normal-sense shear zones. Doming of the southern part of cross section is due to later bivergent extension of region [Gessner et al., 2001b; Ring et al., 2003b]. (b and c) Summary PT diagrams for Selçuk nappe and Ampelos/Dilek nappe. Equilibration of mineral assemblages in mylonitic shear zones occurred at different times and different PT conditions and individual data were combined to tentative PT path (arrows). Note that PT paths from both units differ from each other. 


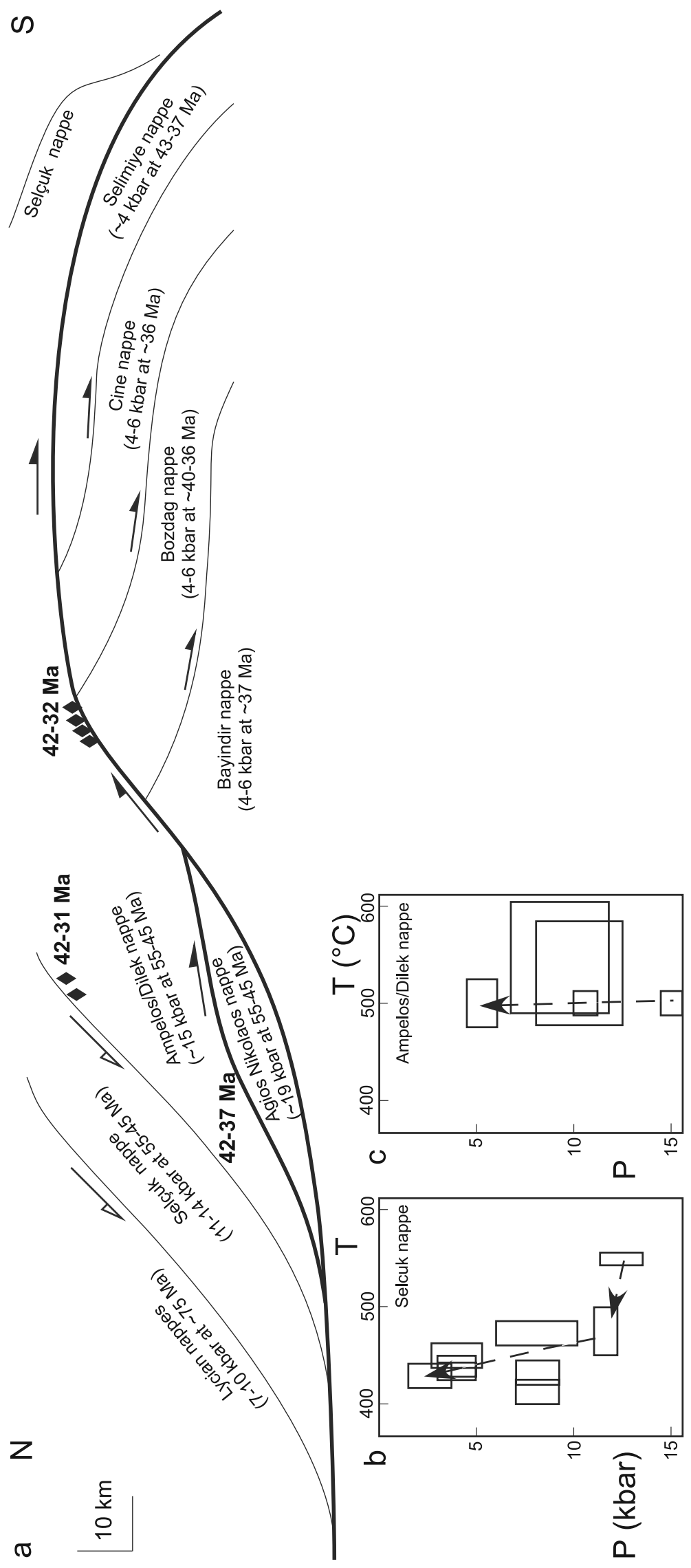


high-pressure conditions at $\sim 42 \mathrm{Ma}$ and continued to move until $\sim 32$ Ma when the high-pressure rocks were considerably retrogressed during final emplacement above the Menderes nappes. The apatite fission track ages of $\sim 34-27 \mathrm{Ma}$ confirm that the high-pressure rocks reached uppermost crustal levels in the early Oligocene. Given the break in metamorphic pressure of $\sim 9-11$ kbar, the Cyclades-Menderes thrust cut out a $\sim 30$ - to $40-\mathrm{km}$-thick section of crust. Assuming a thrust dip of $15-30^{\circ}$ results in a displacement of $60-150 \mathrm{~km}$. This implies that the thrust slipped at average rates of 6-15 $\mathrm{km} \mathrm{Myr}^{-1}$, which are similar to typical plateconvergence rates in the eastern Mediterranean.

[58] The break in metamorphic pressure across the Selçuk normal shear zone is hard to quantify. Final mylonitization at the base of the Selçuk nappe occurred at 3-5 kbar and 420$440^{\circ} \mathrm{C}$ and suggests normal-fault-controlled decompression (from peak pressure of $12.4 \pm 1.2 \mathrm{kbar}$ ) of $\sim 6-11 \mathrm{kbar}$, which relates to $\sim 20-40 \mathrm{~km}$ of exhumation of the Selçuk nappe. Because maximum pressure in the underlying Ampelos/ Dilek nappe is $\sim 15 \mathrm{kbar}$, a PT break of $\sim 10-12 \mathrm{kbar}$ is suggested across the Selçuk extensional fault. Since the Selçuk normal shear zone is subparallel to the basal thrust, it originated as a low-angle normal-sense shear zone and displacement and averaged displacement rates should be similar to the ones from the Cyclades-Menderes thrust.

[59] Coeval movement on two parallel shear zones with opposite shear senses is difficult from a mechanical point of view unless they converge at depth. In Figure 13 we show the Cyclades-Menderes thrust and the Selçuk normal shear zone merging at depth to form the wedge-shaped Ampelos/ Dilek nappe to circumvent the mechanical problem.

[60] The structural data show that ductile deformation was distributed through the entire extruding wedge but that mylonitic deformation was concentrated in the bounding shear zones. Localization of deformation became more pronounced with time. Grujic et al. [2002] and Law et al. [2004] reported a similar structural sequence from the Greater Himalayan crystalline complex. A consequence of this general flow field is that the wall rocks of the shear zones change length in the slip direction and consequently the bounding shear zones are stretching faults in the sense of Means [1989].

\subsection{Early Exhumation of the Cycladic Blueschist Unit in the Eastern Aegean}

[61] The recognition of the late Eocene Selçuk normal shear zone solves the long-standing problem of how the early exhumation of the Cycladic blueschist unit was achieved. The PT estimates from the greenschist-facies metagabbro mylonites from the Selçuk normal shear zone and those from the greenschist-facies mylonite from the Cyclades-Menderes thrust together with the PT data from the underlying Menderes nappes suggest that the Eocene extrusion wedge accomplished the $\sim 30-40 \mathrm{~km}$ of late Eocene exhumation of the Ampelos/Dilek nappe (Figure 13). Ring et al. [2007] reported a similar but slightly younger case for Oligocene extrusional exhumation of the Cycladic blueschist unit on Evia Island.

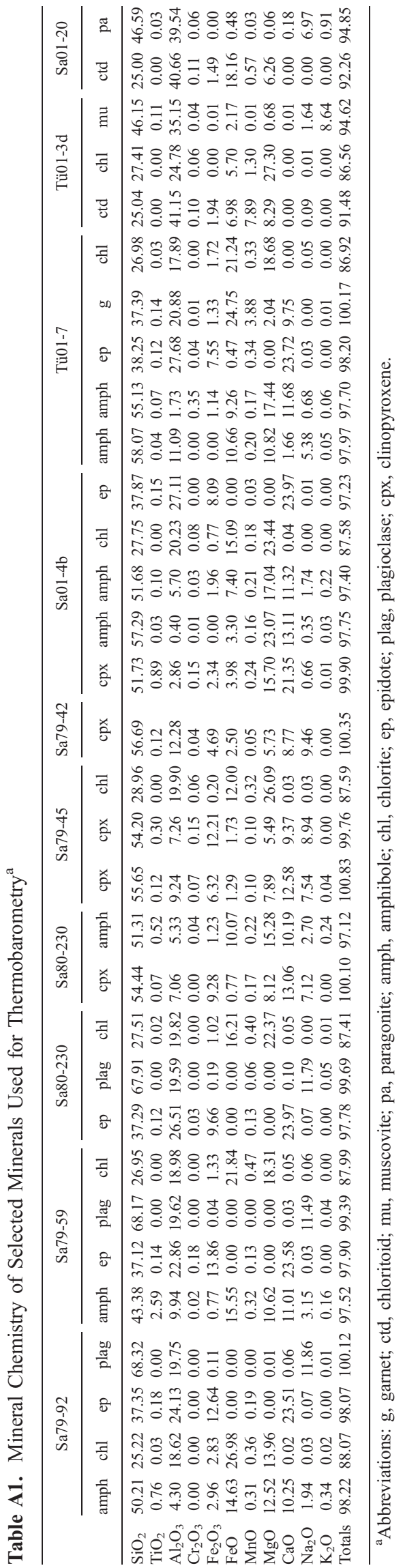


[62] However, how was the Selçuk nappe exhumed? Rimmelé et al. [2003] documented top-to-the-NE/E shearing from the base of the Lycian nappes in southwestern Turkey and speculated that this deformation is related to an Eocene normal fault. The possibility that there were more than one late Eocene normal fault above the Ampelos/Dilek nappe implies that the geometry of the eastern Aegean extrusion wedge was not as simple as depicted in Figure 1 and a wedge with multiple normal-sense shear zones has to be envisaged (Figure 13). Such a scenario is similar to the extrusion wedge made up by the Greater Himalayan crystalline complex. A number of studies [Burg et al., 1984; Burchfiel et al., 1992; Grujic et al., 1996, 2002] have shown that deformation along the upper boundary of the extruding wedge is not restricted to a single fault plane, the south Tibetan detachment, but is distributed in the adjacent footwall and/or hanging wall for up to 3-4 km. Distributed normal-sense shearing above the Ampelos/Dilek nappe can also explain the very limited outcrop and the generally small thickness of the Selçuk nappe across the entire Aegean. In other words, the entire Selçuk nappe represents a heterogeneous normal-sense ductile shear zone. Ring et al. [2007] reported a similar case for the Ochi nappe, which is correlative with the Selçuk nappe, from Evia Island.

[63] We suggest that the cause for the late Eocene extrusion wedge was similar to that of the Miocene extrusion wedge proposed for Crete by Thomson et al. [1999]. Ring and Reischmann [2002] argued that the Cretan detachment was a former subduction thrust that was reactivated as a normal fault as the subduction thrust jumped outboard. The reactivation of the former thrust as a normalsense shear zone is considered a prerequisite for the fast slipping, weak, low-angle nature of the Cretan detachment. If this scenario is applied to the late Eocene extrusion wedge formed by the Ampelos/Dilek nappe, the Selçuk normal shear zone would have to be considered as a former thrust that emplaced the ophiolitic rocks onto the passive-margin sequence and was reactivated as a normal-sense shear zone as thrusting propagated outboard.

[64] Early exhumation of the Ampelos/Dilek nappe is associated with the development of the Cyclades-Menderes thrust at a time when deep underthrusting ceased due to the collision of the Anatolian microcontinent. Ring et al. [1999a] showed that the transition from subduction to continental collision marks a critical period for considerable early exhumation of high- and ultrahigh-pressure rocks. Examples from the Tso-Moari eclogites in the Himalayas [de Sigoyer et al., 2001] and the Alps [Ring, 1995; Reddy et al., 1999; Glodny et al., 2005a] also demonstrate considerable exhumation during the subduction/collision transition.

\section{Conclusions}

[65] We presented evidence for a late Eocene extrusion wedge in the eastern Aegean, thereby providing critical evidence that extrusion wedges might be important for considerable early exhumation of high-pressure units. Our data highlight the importance of the subduction/collision transition and the reactivation of earlier thrust faults for early exhumation of deep-seated units.

[66] The recognition of the Selçuk normal shear zone delimiting the top of this extrusion wedge is the first wellconstrained evidence for an Eocene normal-sense shear zone in the Aegean. The normal-sense shearing is a geometric effect only and not an effect of hypothetic net extension of the region, which instead was undergoing shortening in the late Eocene. The Selçuk normal shear zone is considered to have accomplished $\sim 30-40 \mathrm{~km}$ of exhumation of the Cycladic blueschist unit.

\section{Appendix A}

[67] Selected microprobe analyses of minerals from the island of Samos (samples Sa), eastern Aegean, and western Turkey (samples Tü) are given in Table A1. These analyses were used for the pressure-temperature calculations, whose results are presented in Table 1 in the main body of the text.

[68] Acknowledgments. Funded by the Deutsche Forschungsgemeinschaft (grants Ok2/63 and Ri538/4, Ri538/16, Ri538/23). We thank Djordje Grujic for a very constructive review and Chris Andronicos for editorial handling, Alexander Kühn (Mainz) and Uli Schüssler (Würzburg) for support and help at the microprobe, and Peter Späthe (Würzburg) for superb thin section preparation.

\section{References}

Avigad, D., Z. Garfunkel, L. Jolivet, and J. M. Azanon (1997), Back arc extension and denudation of Mediterranean eclogites, Tectonics, 16, 924-941.

Baldwin, S. L., B. D. Monteleone, L. E. Webb, P. G. Fitzgerald, M. Grove, and E. J. Hill (2005), Pliocene eclogite exhumation at plate tectonic rates in eastern Papua New Guinea, Nature, 431, $263-$ 267.

Brichau, S., U. Ring, A. Carter, R. Ketcham, M. Brunel, and D. Stockli (2006), Constraining the long-term evolution of the slip rate for a major extensional fault system in the central Aegean, Greece, using thermochronology, Earth Planet. Sci. Lett., 241, $293-306$.

Burchfiel, B. C., and L. H. Royden (1985), North-south extension within the convergent Himalayan region, Geology, 13, 679-682.

Burchfiel, B. C., Z. Chen, K. V. Hodges, Y. Liu, L. H. Royden, C. Deng, and J. Xu (1992), The south Tibetan detachment system, Himalayan orogen:
Extension contemporaneous with and parallel to shortening in a collisional mountain belt, Spec. Pap. Geol. Soc. Am., 269, 41.

Burg, J.-P., M. Brunel, D. Gapais, G. M. Chen, and G. H. Liu (1984), Deformation of leucogranites of the crystalline Main Central Sheet in southern Tibet (China), J. Struc. Geol., 6, 535-542.

Catlos, E. J., and I. Çemen (2005), Monazite ages and the evolution of the Menderes Massif, western Turkey, Int. J. Earth Sci., 94, 204-217.

Catlos, E. J., C. S. Dubey, T. M. Harrison, and M. A. Edwards (2004), Late Miocene movement within the Himalayan Main Central Thrust shear zone, Sikkim, north-east India, J. Metamorph. Geol., 22, 207-226.

Challandes, N., D. Marquer, and I. M. Villa (2003), Dating the evolution of $\mathrm{C}-\mathrm{S}$ microstructures: A combined ${ }^{40} \mathrm{Ar} /{ }^{39} \mathrm{Ar}$ step-heating and UV laserprobe analysis of the Alpine Roffna shear zone, Chem. Geol., 197, 3-19.
Cliff, R. A., and S. Meffan-Main (2003), Evidence from $\mathrm{Rb}-\mathrm{Sr}$ microsampling geochronology for the timing of Alpine deformation in the Sonnblick Dome, SE Tauern Window, Austria, in Geochronology: Linking the Isotopic Record With Petrology and Textures, edited by D. Vance, W. Mueller, and I. M. Villa, Geol. Soc. Spec. Publ., 220, 159172 .

Coleman, M. E. (1998), U-Pb constraints on OligoceneMiocene deformation and anatexis within the central Himalaya, Masyandi valley, Nepal, Am. J. Sci., $298,553-571$.

Collins, A. S., and A. H. F. Robertson (1998), Processes of Late Cretaceous to late Miocene episodic thrust sheet translation in the Lycian Taurides, SW Turkey, J. Geol. Soc. London, 155, 759-772.

de Sigoyer, J., V. Chavagnac, J. Blichert-Toft, I. Villa, B. Luais, S. Guillot, M. Cosca, and G. Mascle (2001), Dating the Indian continental subduction and collisional thickening in the northwest Hima- 
laya: Multichronology of the Tso Morari eclogites, Geology, 28, 487-490

Di Vincenzo, G., B. Ghiribelli, G. Giorgetti, and R. Palmeri (2001), Evidence of a close link between petrology and isotope records: constraints from SEM, EMP, TEM and in situ ${ }^{40} \mathrm{Ar}^{-39} \mathrm{Ar}$ laser analyses on multiple generations of white micas (Lanterman Range, Antarctica), Earth Planet. Sci. Lett., 192, 389-405.

Di Vincenzo, G., R. Carosi, and R. Palmeri (2004), The relationship between tectono-metamorphic evolution and argon isotope records in white mica: Constraints from in situ ${ }^{40} \mathrm{Ar}-{ }^{39} \mathrm{Ar}$ laser analysis of the Variscan basement of Sardinia, J. Petrol., 45, $1013-1043$.

Dunlap, W. J. (1997), Neocrystallization or cooling? ${ }^{40} \mathrm{Ar}{ }^{39} \mathrm{Ar}$ ages of white micas from low-grade mylonites, Chem. Geol., 143, 181-203.

Dürr, S., R. Altherr, J. Keller, M. Okrusch, and E. Seidel (1978), The median Aegean crystalline belt: Stratigraphy, structure, metamorphism, magmatism, in Alps, Apeninnes, Hellenides, edited by $\mathrm{H}$. Closs et al., pp. 537-564, Schweizerbart, Stuttgart, Germany.

Federico, L., G. Capponi, L. Crispini, M. Scambelluri, and I. M. Villa (2005), ${ }^{39} \mathrm{Ar} /{ }^{40} \mathrm{Ar}$ dating of highpressure rocks from the Ligurian Alps: Evidence for a continuous subduction-exhumation cycle, Earth Planet. Sci. Lett., 240, 668-680.

Franz, L., and M. Okrusch (1992), Aragonite-bearing blueschists on Arki Island, Dodecanese, Greece, Eur. J. Mineral., 4, 527-537.

Freeman, S. R., S. Inger, R. W. H. Butler, and R. A Cliff (1997), Dating deformation using $\mathrm{Rb}-\mathrm{Sr}$ in white mica: Greenschist facies deformation ages from the Entrelor shear zone, Italian Alps, Tectonics, $16,57-76$.

Gessner, K., U. Ring, C. W. Passchier, and T. Güngör (2001a), How to resist subduction: evidence for large-scale out-of-sequence thrusting during Eocene collision in western Turkey, J. Geol. Soc. London, $158,769-784$.

Gessner, K., U. Ring, C. Johnson, R. Hetzel, C. W. Passchier, and T. Güngör (2001b), An active bivergent rolling-hinge detachment system: The central Menderes metamorphic core complex in western Turkey, Geology, 29, 611-614.

Glodny, J., U. Ring, A. Kühn, P. Gleissner, and G. Franz (2005a), Crystallization and very rapid exhumation of the youngest Alpine eclogites (Tauern Window, eastern Alps) from $\mathrm{Rb} / \mathrm{Sr}$ mineral assemblage analysis, Contrib. Mineral. Petrol., 149, 699-712, doi:10.1007/s00410-005-0676-5.

Glodny, J., J. Lohrmann, H. Echtler, K. Gräfe, W. Seifert, S. Collao, and O. Figueroa (2005b), Internal dynamics of a paleoaccretionary wedge: insights from combined isotope tectonochronology and sandbox modeling of the South-Central Chilean forearc, Earth Planet. Sci. Lett., 231, 23-39.

Green, P. F., I. R. Duddy, G. M. Laslett, K. A. Hegarty, A. J. W. Gleadow, and J. F. Lovering (1989), Thermal annealing of fission tracks in apatite, 4, Quantitative modelling techniques and extension to geological timescale, J. Petrol. Geol., 12, 111-114.

Grujic, D., M. Casey, C. Davidson, L. S. Hollister, R. Kündig, T. Pavlis, and S. Schmid (1996), Ductile extrusion of the Higher Himalayan Crystalline in Bhutan: evidence from quartz microfabrics, Tectonophysics, 260, 21-43.

Grujic, D., L. Hollister, and R. Parrish (2002), Himalayan metamorphic sequence as an orogenic channel: insight from Bhutan, Earth Planet. Sci. Lett., 198, 177-191.

Harrison, T. M., F. J. Ryerson, P. Le Fort, A. Yin, O. M. Lovera, and E. J. Catlos (1997), A late MiocenePliocene origin for the central Himalaya inverted metamorphism, Earth Planet. Sci. Lett., 146, 1-8.

Hetzel, R., and T. Reischmann (1996), Intrusion age of Pan-African augen gneiss in the southern Menderes Massif and the age of cooling after Alpine ductile extensional deformation, Geol. Mag., 133, 565-572.

Hodges, K. V., R. R. Parrish, T. B. Housh, D. R. Lux, B. C. Burchfiel, L. H. Royden, and Z. Chen
(1992), Simultaneous Miocene extension and shortening in the Himalayan Orogen, Science, $258,1466-1470$

Hodges, K. V., R. R. Parrish, and M. P. Searle (1996), Tectonic evolution of the central Annapurna Range, Nepalese Himalayas, Tectonics, 15, 1264-1291.

Hodges, K. V., S. A. Bowring, K. L. Davidek, D. Hawkins, and M. Krol (1998), Evidence for rapid displacement on Himalayan normal faults and the importance of tectonic denudation in the evolution of mountain ranges, Geology, 26, 483-486.

Holland, T. J. B. (1980), The reaction albite $=$ jadeite + quartz determined experimentally in the range $600-1200^{\circ} \mathrm{C}$, Am. Mineral., 65, 129-134.

Holland, T. J. B., and R. Powell (1998), An internally consistent thermodynamic data set for phases of petrological interest, J. Metamorph. Geol., 16, 309-344.

Hurford, A. J. (1990), Standardization of fission-track dating calibration: Recommendation by the Fission Track Working Group of the I.U.G.S, Subcommission on Geochronology, Chem. Geol., 80, $171-$ 178

Keay, S., G. S. Lister, and I. S. Buick (2001), The timing of partial melting, Barrovian metamorphism and granite intrusion in the Naxos metamorphic core complex, Cyclades, Aegean Sea, Greece, Tectonophysics, 342, 275-312.

Kühn, A., J. Glodny, K. Iden, and A. Austrheim (2000), Retention of Precambrian $\mathrm{Rb} / \mathrm{Sr}$ phlogopite ages through Caledonian eclogite facies metamorphism, Bergen Arc Complex, W-Norway, Lithos, 51, $305-$ 330.

Kumerics, C., U. Ring, S. Brichau, J. Glodny, and P. Monié (2005), The extensional Messaria shea zone and associated brittle detachment faults, Aegean Sea, Greece, J. Geol. Soc. London, 162, 701-721, doi:10.1144/0016-764904-041.

Law, R. D., M. P. Searle, and R. L. Simpson (2004), Strain, deformation temperatures and vorticity of flow at the top of the Greater Himalayan Slab, Everes Massif, Tibet, J. Geol. Soc. London, 161, 305-320.

Lips, A. L. W., D. Cassard, H. Sözbilir, H. Yilmaz, and J. R. Wijbrans (2001), Multistage exhumation of the Menderes Massif, western Anatolia (Turkey), Int J. Earth Sci., 89, 781-792.

Lister, G. S., G. Banga, and A. Feenstra (1984), Metamorphic core complexes of Cordilleran type in the Cyclades, Aegean Sea, Greece, Geology, 12, $21-25$.

Ludwig, K. R. (1999), Isoplot/Ex Ver 2.06. A geochronological toolkit for Microsoft Excel, Spec. Publ. 1a, Berkeley Geochronol. Center, Berkeley, Calif.

Means, W. D. (1989), Stretching faults, Geology, 17 $893-896$.

Mulch, A., and M. A. Cosca (2004), Recrystallization or cooling ages: In situ UV-laser ${ }^{40} \mathrm{Ar} /{ }^{39} \mathrm{Ar}$ geochronology of muscovite in mylonitic rocks, J. Geol. Soc. London, 161, 573-582.

Müller, W., R. D. Dallmeyer, F. Neubauer, and M. Thöni (1999), Deformation-induced resetting of $\mathrm{Rb} / \mathrm{Sr}$ and ${ }^{40} \mathrm{Ar} /{ }^{39} \mathrm{Ar}$ mineral systems in a lowgrade, polymetamorphic terrane (eastern Alps, Austria), J. Geol. Soc. London, 156, 261-278.

Müller, W., D. Aerden, and A. N. Halliday (2000), Isotopic dating of strain fringe increments: duration and rates of deformation in shear zones, Science, 288, 2195-2198

Müller, W., G. Prosser, N. S. Mancktelow, I. M. Villa, S. P. Kelley, G. Viola, and F. Oberli (2001), Geochronological constraints on the evolution of the Periadriatic Fault System (Alps), Int. J. Earth Sci., $90,623-653$

Murphy, M. A., and T. M. Harrison (1999), Relationship between leucogranites and the Qomolangma detachment in the Rongbuk valley, south Tibet, Geology, 27, 831-834.

Oberhänsli, R., J. H. Partzsch, O. Candan, and M. Çetinkaplan (2001), First occurrence of Fe-Mg-carpholite documenting a high pressure metamorphism in metasediments of the Lycian Nappes, SW Turkey, Int. J. Earth Sci., 89 $863-869$.
Powell, R., and T. J. B. Holland (1994), Optimal geothermometry and geobarometry, Am. Mineral., $79,120-133$.

Reddy, S. M., S. P. Kelley, and L. Magennis (1997), A microstructural and argon laserprobe study of shear zone development on the western margin of the Nanga Parbat syntaxis, north Pakistan, Contrib. Mineral. Petrol., 128, 16-29.

Reddy, S. M., J. Wheeler, and R. A. Cliff (1999), The geometry and timing of orogenic extension: An example from the western Italian Alps, J. Metamorph. Geol., 17, 573-589.

Reddy, S. M., J. Wheeler, R. W. H. Butler, R. A. Cliff, S. Freeman, S. Inger, C. Pickles, and S. P. Kelley (2003), Kinematic reworking and exhumation within the convergent Alpine Orogen, Tectonophysics, $365,77-102$

Régnier, J.-L., U. Ring, C. W. Passchier, T. Güngör, and K. Gessner (2003), Contrasting metamorphic evolution of metasediments from the Çine and Selimiye nappes in the southern Anatolide belt, western Turkey, J. Metamorph. Geol., 21, 699-721.

Rimmelé, G., L. Jolivet, R. Oberhänsli, and B. Goffé (2003), Deformation history of the high-pressure Lycian Nappes and implications for tectonic evolution of SW Turkey, Tectonics, 22(2), 1007, doi:10.1029/2001TC901041.

Ring, U. (1995), Horizontal contraction or horizonta extension?: Heterogeneous Late Eocene and Early Oligocene general shearing during blueschist- and greenschist-facies metamorphism at the PennineAustroalpine boundary zone in the western Alps, Geol. Rundsch., 84, 843-859.

Ring, U., and P. W. Layer (2003), High-pressure metamorphism in the Aegean, eastern Mediterranean: Underplating and exhumation from the Late Cretaceous until the Miocene to Recent above the retreating Hellenic subduction zone, Tectonics, 22(3), 1022, doi:10.1029/2001TC001350.

Ring, U., and T. Reischmann (2002), The weak and superfast Cretan detachment, Greece: Exhumation at subduction rates in extrusion wedges, J. Geol. Soc. London, 159, 225-228.

Ring, U., M. T. Brandon, S. D. Willett, and G. S. Lister (1999a), Exhumation processes, in Exhumation Processes: Normal Faulting, Ductile Flow and Erosion, edited by U. Ring et al., Geol. Soc. Spec. Publ., 154, 1-27.

Ring, U., S. Laws, and M. Bernet (1999b), Structura analysis of a complex nappe sequence and lateorogenic basins from the Aegean Island of Samos, Greece, J. Struct. Geol., 21, 1575-1601.

Ring, U., K. Gessner, T. Güngör, and C. W. Passchier (1999c), The Menderes belt of western Turkey and the Cycladic belt in the Aegean-Do they really correlate?, J. Geol. Soc London, 156, 3-6.

Ring, U., P. W. Layer, and T. Reischmann (2001a), Miocene high-pressure metamorphism in the Cyclades and Crete, Aegean Sea, Greece: Evidence for large-magnitude displacement on the Cretan detachment, Geology, 29, 395-398.

Ring, U., A. Willner, and W. Lackmann (2001b), Nappe stacking and clockwise versus anticlockwise pressure-temperature paths: An example from the Menderes nappes of western Turkey, Am. J. Sci., 301, $912-944$

Ring, U., S. N. Thomson, and M. Bröcker (2003a), Fast extension but little exhumation: the Vari detachmen in the Cyclades, Greece, Geol. Mag., 140, 245-252.

Ring, U., C. Johnson, R. Hetzel, and K. Gessne (2003b), Tectonic denudation of a Late Cretaceous-Tertiary collisional belt: Regionally symmetric cooling patterns and their relation to extensional faults in the Anatolide belt of western Turkey, Geol. Mag., 140, 421-441.

Ring, U., J. Glodny, T. Will, and S. Thomson (2007), An Oligocene extrusion wedge of blueschist-facie nappes on Evia Island, Aegean Sea, Greece: Implications for the early exhumation of high-pressure rocks, J. Geol. Soc. London, doi:10.1144/001676492006-041, in press.

Robertson, A. H. F., P. Clift, P. J. Degnan, and G. Jones (1991), Palaeogeographic and palaeotectonic evolu- 
tion of the eastern Mediterranean Neotethys, Palaeogeogr. Palaeoclimatol., 87, 243-289.

Rubatto, D., and J. Herrmann (2001), Exhumation as fast as subduction?, Geology, 29, 3-6.

Samson, S. D., and E. C. Alexander (1987), Calibration of the interlaboratory ${ }^{40} \mathrm{Ar} /{ }^{39} \mathrm{Ar}$ dating standard, MMhb-1, Chem. Geol., 66, 27-34.

Scaillet, S., G. Feraud, M. Ballevre, and M. Amouric (1992), $\mathrm{Mg} / \mathrm{Fe}$ and $\left[(\mathrm{Mg}, \mathrm{Fe}) \mathrm{Si}_{-} \mathrm{Al}_{2}\right]$ compositional control on argon behaviour in high-pressure white micas: $\mathrm{A}{ }^{40} \mathrm{Ar} /{ }^{39} \mathrm{Ar}$ continuous laser-probe study from the Dora-Maira nappe of the internal western Alps, Italy, Geochim. Cosmochim. Acta, 56, $2851-$ 2872.

Seidel, E., H. Kreuzer, and W. Harre (1982), A late Oligocene/early Miocene high pressure belt in the External Hellenides, Geol. Jahrb., Reihe E, 23, $165-206$.

Sherlock, S., S. Kelley, S. Inger, N. Harris, and A. Okay (1999), ${ }^{40} \mathrm{Ar}-{ }^{39} \mathrm{Ar}$ and $\mathrm{Rb}-\mathrm{Sr}$ geochronology of high-pressure metamorphism and exhumation history of the Tavsanli Zone, NW Turkey, Contrib. Mineral. Petrol., 137, 46-58.

Thomson, S. N., B. Stöckhert, and M. A. Brix (1998), Thermochronology of the high-pressure metamorphic rocks of Crete, Greece: Implications for the speed of tectonic processes, Geology, 26, $259-262$.

Thomson, S. N., B. Stöckhert, and M. A. Brix (1999), Miocene high-pressure metamorphic rocks of Crete, Greece: Rapid exhumation by buoyant escape, in Exhumation Processes: Normal Faulting, Ductile
Flow and Erosion, edited by U. Ring et al., Geol. Soc. Spec. Publ., 154, 87-108.

Tomaschek, F., A. Kennedy, I. Villa, M. Lagos, and C. Ballhaus (2003), Zircons from Syros, Cyclades, Greece-Recrystallization and mobilization during high pressure metamorphism, J. Petrol., 44, $1977-$ 2002.

van Hinsbergen, D. J. J., W. J. Zachariasse, M. J. R. Wortel, and J. E. Meulenkamp (2005), Underthrusting and exhumation: A comparison between the External Hellenides and the "hot" Cycladic and "cold" South Aegean core complexes (Greece), Tectonics, 24, TC2011, doi:10.1029/ 2004TC001692.

Villa, I. (1998), Isotopic closure, Terra Nova, 10, $42-$ 47.

von Blanckenburg, F., I. M. Villa, H. Baur, G. Morteani, and R. H. Steiger (1989), Time calibration of a PT-path from the Western Tauern Window, eastern Alps: The problem of closure temperatures, Contrib. Mineral. Petrol., 101, 1-11.

Whitney, D. L., and E. Bozkurt (2002), Metamorphic history of the southern Menderes Massif, southern Turkey, Geol. Soc. Am. Bull., 114, 829-838.

Wijbrans, J. R., M. Schliestedt, and D. York (1990), Single grain argon laser probe dating of phengites from the blueschist to greenschist transition on Sifnos (Cyclades, Greece), Contrib. Mineral. Petrol. 104, 582-593.

Will, T., M. Okrusch, E. Schmädicke, and G. Chen (1998), Phase relations in the greenschist-blueschistamphibolite-eclogite facies in the system $\mathrm{Na}_{2} \mathrm{O}$
$\mathrm{CaO}-\mathrm{FeO}-\mathrm{MgO}-\mathrm{Al}_{2} \mathrm{O}_{3}-\mathrm{SiO}_{2}-\mathrm{H}_{2} \mathrm{O}$ (NCFMASH), with application to metamorphic rocks from Samos, Greece, Contrib. Mineral. Petrol., 132, 85-102.

K. Drüppel, Institut für Mineralogie, Technische Universität, D-10587 Berlin, Germany.

K. Gessner, School of Earth and Geographical Sciences, University of Western Australia, Crawley WA 6008, Australia. (kgessner@cyllene.uwa.edu.au)

J. Glodny, GeoForschungsZentrum Potsdam, D-14473 Potsdam, Germany. (glodnyj@gfz-potsdam.de)

T. Güngör, Jeoloji Mühendisligi Bölümü, Dokuz Eylül Üniversitesi, 35100 Bornova, Turkey.

C. Kumerics, Institut für Geowissenschaften, Johannes Gutenberg-Universität, D-55099 Mainz, Germany. (kumerics@uni-mainz.de)

P. Monié, UMR 5573, Université Montpellier II, 34095 Montpellier, France. (patrick.monie@dstu. univ-montp2.fr)

M. Okrusch and T. Will, Institut für Mineralogie, Universität Würzburg, D-97074 Würzburg, Germany. (okrusch@mail.uni-wuerzburg.de; thomas.will@mail. uni-wuerzburg.de)

U. Ring, Department of Geological Sciences, Canterbury University, Christchurch 8004, New Zealand. (uwe.ring@canterbury.ac.nz)

S. Thomson, Department of Geology and Geophysics, Yale University, New Haven, CT 06520, USA (stuart.thomson@yale.edu) 